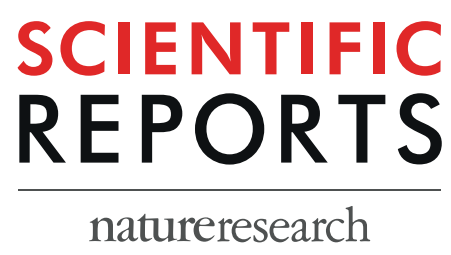

\title{
Potential Inhibitors of Galactofuranosyltransferase 2 (GIfT2): Molecular Docking, 3D-OSAR, and In Silico ADMETox Studies
}

\begin{abstract}
Christopher Llynard D. Ortiz ${ }^{1,2,3}$, Gladys C. Completo ${ }^{1,3}$, Ruel C. Nacario ${ }^{1,3}$ \& Ricky B. Nellas ${ }^{2,3^{*}}$
A strategy in the discovery of anti-tuberculosis (anti-TB) drug involves targeting the enzymes involved in the biosynthesis of Mycobacterium tuberculosis' (Mtb) cell wall. One of these enzymes is Galactofuranosyltransferase 2 (GIfT2) that catalyzes the elongation of the galactan chain of $M t b$ cell wall. Studies targeting GIfT2 have so far produced compounds showing minimal inhibitory activity. With the current challenge of designing potential GIfT2 inhibitors with high inhibition activity, computational methods such as molecular docking, receptor-ligand mapping, molecular dynamics, and ThreeDimensional-Quantitative Structure-Activity Relationship (3D-OSAR) were utilized to deduce the interactions of the reported compounds with the target enzyme and enabling the design of more potent GIfT2 inhibitors. Molecular docking studies showed that the synthesized compounds have binding energy values between -3.00 to $-6.00 \mathrm{kcal} \mathrm{mol}^{-1}$. Two compounds, \#27 and \#31, have registered binding energy values of $-8.32 \pm 0.01$, and $-8.08 \pm 0.01 \mathrm{kcal} \mathrm{mol}^{-1}$, respectively. These compounds were synthesized as UDP-Galactopyranose mutase (UGM) inhibitors and could possibly inhibit GIfT2. Interestingly, the analogs of the known disaccharide substrate, compounds \#1-4, have binding energy range of -10.00 to $-19.00 \mathrm{kcal} \mathrm{mol}^{-1}$. The synthesized and newly designed compounds were subjected to 3D-OSAR to further design compounds with effective interaction within the active site. Results showed improved binding energy from -6.00 to $-8.00 \mathrm{kcal} \mathrm{mol}^{-1}$. A significant increase on the binding affinity was observed when modifying the aglycon part instead of the sugar moiety. Furthermore, these top hit compounds were subjected to in silico ADMETox evaluation. Compounds \#31, \#70, \#71, \#72, and \#73 were found to pass the ADME evaluation and throughout the screening, only compound \#31 passed the predicted toxicity evaluation. This work could pave the way in the design and synthesis of GIfT2 inhibitors through computer-aided drug design and can be used as an initial approach in identifying potential novel GIfT2 inhibitors with promising activity and low toxicity.
\end{abstract}

Tuberculosis (TB) has been one of the fatal diseases worldwide ${ }^{1-3}$. The causative agent of this disease is a pathogenic microorganism, Mycobacterium tuberculosis $(M t b)$, which is a rod-shaped mycobacteria ${ }^{4}$. The World Health Organization (WHO) recently reported that one-third of world's population ${ }^{5}$ has TB. There is still a slow decline on the number of infected individuals for the previous years ${ }^{6}$, concluding that current efforts to fight this disease is challenging. In the Philippines, TB has been identified as the sixth leading cause of morbidity and mortality, which makes the country ranked sixth out of the top $22 \mathrm{~TB}$ burdened countries worldwide ${ }^{7}$. In addition, the Philippines is considered one of the countries with the highest number of cases of multi-drug resistant tuberculosis (MDR-TB $)^{8}$. Despite active efforts in administering the latest medical treatment to prevent the spread of TB, this pulmonary illness remains a global threat.

${ }^{1}$ Institute of Chemistry, College of Arts and Sciences, University of the Philippines Los Banos, College, Laguna, 4031, Philippines. ${ }^{2}$ Institute of Chemistry, College of Science, University of the Philippines Diliman, Diliman, Quezon City, 1101, Philippines. ${ }^{3}$ These authors contributed equally: Christopher Llynard D. Ortiz, Gladys C. Completo, Ruel C. Nacario and Ricky B. Nellas. *email: rbnellas@up.edu.ph 
<smiles>OCC1C(O)C(O)C(O)C(O)C1O</smiles>

14

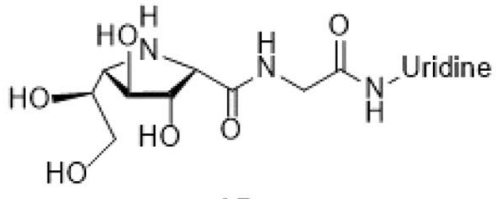

15

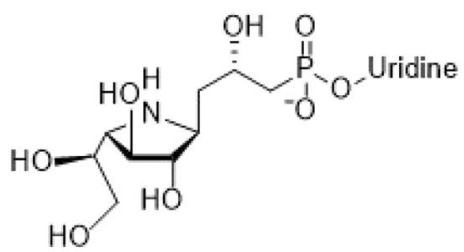

17<smiles>CCOC(=O)CCC1NC(CC(O)CO)C(O)C1CO</smiles>

18

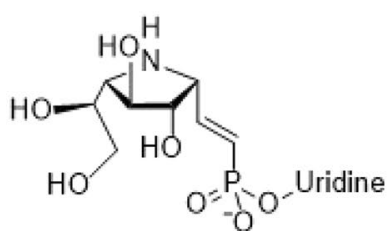

16

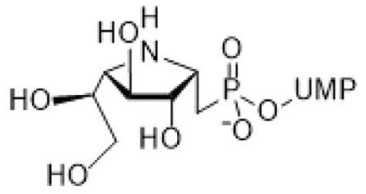

19

Figure 1. Structures of Imino-Sugars as GlfT2 inhibitors.

There are two kinds of resistance to TB: (a) mono and (b) poly resistant. The latter is divided into two: (a) multi-drug resistant (MDR-TB), to at least two of the standard or first-line anti-TB drugs, and (b) extensively/ extreme-drug resistant (XDR-TB), to at least two of the first-line anti-TB drugs and is immune to the second-line anti-TB drugs. The inconsistent TB treatment for patients has led to a new strain that is totally drug-resistant (TDR-TB) to either the first-line or second-line anti-TB drugs ${ }^{9,10}$. There is currently no known treatment for TDR-TB; thus, this opens up the challenge of developing new strategies on design of new anti-TB drugs.

Mycobacterium species' cell wall acts as a rigid scaffold that hinders the penetrating action of antibiotics. Some commercially-available anti-TB drugs (i.e. ethambutol or isoniazid) are used to disrupt the cell wall biosynthesis $^{11-13}$, in combination with other anti-TB drug (i.e. rifampicin or streptomycin) that have intracellular targets ${ }^{14}$. Current anti-TB treatment, i.e. DOTS ${ }^{15}$, targets the $M t b$ cell wall's integrity and allow the facile permeation of the antibiotics to the organism. The microorganism's ability to adapt and develop resistance to these drugs is still a challenge. This continuing battle is evident in the emergence of resistant strains responsible for MDR-, XDR-, and TDR-TB in some regions of the world. Hence, a potential strategy for TB treatment is in the search for novel compounds that can interfere with the $M t b$ 's cell wall complex biosynthesis.

$M t b$ 's cell wall efficiently protects the mycobacteria from detrimental factors during the infection stage, at the same time, it could also be the weak spot of the organism ${ }^{16}$. One component of the $M t b$ 's cell wall is the arabinogalactan $(\mathrm{AG})$ complex. This is a unique structure that is composed of D-galactofuranosyl and L-arabinofuranosyl monosaccharides ${ }^{17}$. The AG complex, like any other carbohydrate polymers, is essential for mycobacterial viability ${ }^{18,19}$. Thus, the enzymes involved in its biosynthesis might serve as putative therapeutic targets. One of the enzymes involved in the synthesis of this complex is Galactofuranosyltransferase 2 (GlfT2), an enzyme that catalyzes the transfer of galactofuranosyl residues from UDP-Gal $f$ to the growing galactan $\operatorname{chain}^{20,21}$. This chain is composed of $\sim 30 \mathrm{D}$-galactofuranose (Galf) residues that are linked via alternating $\beta$ - $(1 \rightarrow 5)$ and $\beta$ $(1 \rightarrow 6)$ linkages with the reducing end covalently attached to a linker disaccharide consisting of rhamnose and $\mathrm{N}$-acetylglucosamine ${ }^{22}$.

Several active researches have zoomed in on GlfT2 inhibitors as anti-TB drugs. Current strategies in the design of GlfT2 inhibitors involved mimicking either the donor or acceptor substrate of the enzyme ${ }^{16,21,23}$. Uridine diphosphate-galactofuranose (UDP-Galf) is considered the donor substrate of GlfT2. The approach used is to design a glycomimetic compound with disrupted hydrogen-bonding interaction with the enzyme's catalytic site, specifically with D372, through modification of the 6-OH position ${ }^{16}$. With this strategy, four compounds were synthesized such as the UDP-6-fluoro- $\alpha$-D-Galf (compound \#49), the UDP- $\beta$-L-Araf (compound \#50), the UDP5 -deoxy- $\alpha$-D-Gal $f$ (compound \#51), and the UDP-6-deoxy- $\alpha$-D-Galf (compound \#52). Compounds \#50 and \#52 were found to inhibit the production of the glycolipids and compounds \#49 and \#51 have effectively reduced the length of galactolipid produced ${ }^{16}$.

The drawback of using the aforementioned compounds is in their inability to pass through the cell membrane because of the polar sugar moiety and charged diphosphate group. Thus, another strategy was proposed by replacing the diphosphate group of UDP-Gal $f$ with basic amino acids such as lysine, glutamine, tryptophan, and histidine. Also, instead of using D-Galf, L-Ara $f$ was used. Among the four sugar-amino acid-nucleosides, those with tryptophan and histidine as the replacement for the diphosphate moiety have shown $30 \%$ and $37 \%$ inhibition activity with GlfT2 $2^{23}$, respectively.

Another series of GlfT2's donor-mimicking inhibitors are compounds \#15-18 (Fig. 1). These are structurally described as imino-galactofuranose sugar moieties with uridine as an aglycon. These compounds only differ in linker composition that is an amide (compound \#15) ${ }^{24}$, phosphate and double bond (compound \#16) ${ }^{25,26}$ and phosphate and a hydroxyl group (compound \#17) ${ }^{27}$. Compound \#18 (Fig. 1) is considered an analog of compound $\# 17^{28}$. Furthermore, compound \#19 (Fig. 4) is an imino-galactofuranose with UDP as an aglycon. These probes were previously used as UDP-galactopyranose mutase (UGM) inhibitors ${ }^{26}$. It was found that only compound \#18 exhibited less than 35\% inhibition activity against $\mathrm{UGM}^{26}$. 
<smiles>CCCCCCCCO[C@H]1OC([C@@H](CO)O[C@@H]2O[C@H]([C@@H](O)CO)[C@@H](O)[C@H]2O)[C@H](O)[C@H]1O</smiles>

\section{3}<smiles>CCCCCCCCO[C@H]1O[C@H](C(O)CO[C@@H]2O[C@H]([C@@H](O)CO)[C@@H](O)[C@H]2O)[C@H](O)[C@H]1O</smiles>

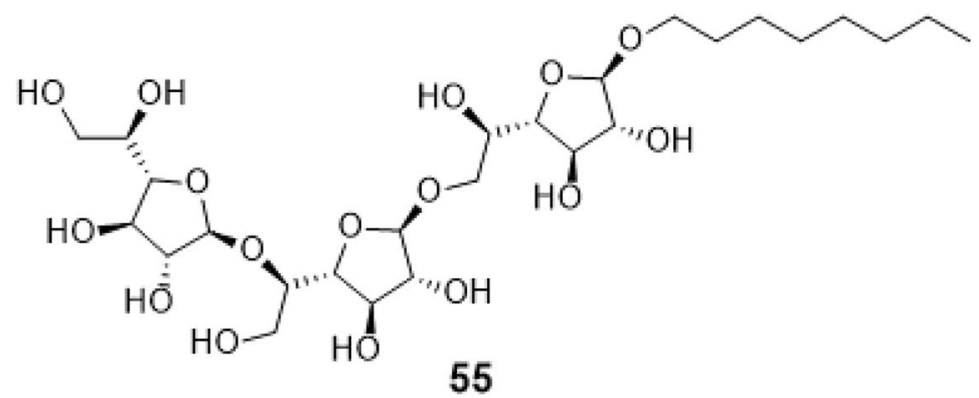<smiles>CCCCCCCCO[C@H]1O[C@H](C(O)CO[C@@H]2O[C@H](C(O)CO[C@@H]3O[C@H]([C@@H](O)CO)[C@H](O)[C@H]3O)[C@@H](O)[C@H]2O)[C@H](O)[C@@H]1O</smiles>

Figure 2. Structures of Synthetic Acceptor Substrates as GlfT2 inhibitors.

A previous study synthesized compounds \#53-56 (Fig. 2) to evaluate GlfT's specificity ${ }^{16}$. These compounds are octyl di- and tri-saccharides. Using kinetic characterization of GlfT with these compounds, it was found that trisaccharides were better substrates than disaccharides. The current strategy in designing for the acceptor mimic substrates were based from these results.

Aside from mimicking the donor and acceptor substrates to inhibit GlfT2, making a resemblance of the positive character of the transition state of the substrate was also used. A recent study synthesized 14 sulfonium ions with varying side chains. These are expected to mimic the transition state during the glycosyl transfer reaction. Among these compounds, the one having a sulfonium ion with 12-hydroxydodecyl side chain exhibited the highest inhibition activity of $60 \%{ }^{29}$.

Both glycosidase and galactofuranosyltransferase carry out glycosyl transfer reaction, hence, it is noteworthy that the proposed inhibitors of glycosidase may also potentially serve as GlfT2 inhibitors ${ }^{29}$. Compound \#24 
<smiles>O=S(=O)([O-])O[C@@H](CO)[C@@H](O)CN[C@@H]([C@H](O)CO)[C@H](O)[C@H](O)C[C@H](O)CO</smiles>

23<smiles>O=S(=O)([O-])OC(CO)[C@H](O)CS[C@H]1C[C@H](O)[C@@H](O)[C@H]1[C@H](O)CO</smiles>

24<smiles>O=S(=O)(O)O[C@@H]1C[C@@H](O)[C@@H](O)[C@H]1[C@H](O)CO</smiles>

25

Figure 3. Structures of the Transition State Mimics as GlfT2 inhibitors.

\begin{tabular}{|l|l|l|}
\hline Compounds & $\begin{array}{l}\text { Binding energy } \\
(\mathbf{k c a l} / \mathbf{m o l})\end{array}$ & $\begin{array}{l}\text { Inhibition } \\
\text { constant, } \boldsymbol{\mu M}\end{array}$ \\
\hline Natural substrate & $-6.63 \pm 0.02$ & 14 \\
\hline streptomycin & $-6.25 \pm 0.01$ & 26 \\
\hline rifampicin & $-6.19 \pm 0.04$ & 29 \\
\hline ethambutol & $-4.12 \pm 0.01$ & 950 \\
\hline isoniazid & $-4.44 \pm 0.01$ & 553 \\
\hline pyrazinamide & $-4.04 \pm 0.01$ & 1078 \\
\hline
\end{tabular}

Table 1. Binding affinities and Inhibition constant $(\mathrm{T}=298.15 \mathrm{~K})$ of first-line Anti-TB drugs.

\begin{tabular}{|c|c|c|c|c|c|c|c|c|c|c|c|c|c|c|c|}
\hline \multirow{2}{*}{\begin{tabular}{|l|} 
Compounds \\
Natural substrate \\
\end{tabular}} & \multicolumn{8}{|c|}{ Major interacting amino acids } & \multicolumn{7}{|c|}{ Additional interacting amino acids } \\
\hline & Y236 & D256 & W309 & W348 & K369 & D372 & W399 & Q409 & & & & & & & \\
\hline Streptomycin & Y236 & & & W348 & K369 & & & & P167 & & G232 & H396 & I368 & F169 & \\
\hline Rifampicin & & & & & K369 & & & & & & & & & & \\
\hline \multicolumn{16}{|l|}{ Ethambutol } \\
\hline Isoniazid & & & & & & & & & & Q200 & & & & & \\
\hline Pyrazinamide & & & & & & & & & P167 & & G232 & & I368 & & T168 \\
\hline
\end{tabular}

Table 2. Interacting amino acids with First-line anti-TB drugs.

(Fig. 3) is one of the two naturally-occurring sulfonium ion glycosidase inhibitors, known as salacinol ${ }^{30}$. This compound was found to have an inhibitory activity towards $\alpha$-glycosidase. Compounds \#23 and \#25 (Fig. 3 ) are both salacinol-derivatives replacing sulfur atom with nitrogen and selenium, respectively ${ }^{31,32}$.

With regard to the charged-sulfur containing compounds as GlfT2 inhibitors, a series of galactofuranosyl $\mathrm{N}, \mathrm{N}$ '-dialkyl sulfenamides and sulfonamide were synthesized. Here, it was found that compounds with shorter $\mathrm{N}, \mathrm{N}$ '-dihexyl chains showed low inhibition activity compared with compounds having longer dioctyl and didecyl chains $^{34}$.

The potential GlfT2 inhibitors aforementioned have low inhibition activities with the enzyme. As such, it is timely to shift and find another strategy on designing new GlfT2 inhibitors. In silico studies such as molecular docking and 3D-QSAR are now possible with the availability of the GlfT2 crystal structure (PDB ID: 4FIX) ${ }^{20}$. Molecular dynamics (MD) simulations were performed to obtain ensemble of protein structures to be used for molecular docking studies. Also, 3D-QSAR was used as guide in designing new GlfT2 inhibitors. Moreover, the top hit compounds were screened using in silico ADMETox.

\section{Results and Discussion}

Ensemble docking. The 100 different protein conformations were obtained from the entire $100 \mathrm{~ns}$ simulation using the clustering analysis of the cpptraj ${ }^{35}$ module of the AMBERTools 15 package ${ }^{36}$. Previously synthesized and functionalized compounds were prepared using the MarvinSketch software ${ }^{37}$. Subsequently, molecular docking was performed using AutoDock Vina ${ }^{38-40}$. Here, the inhibition constant $(\mathrm{K} i$ ) was obtained from the binding energy $(\Delta \mathrm{G})$ using the formula: $\mathrm{K} i=\exp (\Delta \mathrm{G} / \mathrm{RT})$, where $\mathrm{R}$ is the universal gas constant $\left(1.985 \times 10^{-3}\right.$ $\left.\mathrm{kcal} \mathrm{mol}^{-1} \mathrm{~K}^{-1}\right)$ and $\mathrm{T}$ is the temperature $(298.15 \mathrm{~K})$. The previously synthesized and functionalized compounds were docked to obtain the binding energy of the complexes formed between the receptor and the ligands. The natural acceptor substrate was found to have a binding energy of $-6.63 \pm 0.02 \mathrm{kcal} \mathrm{mol}^{-1}$ and Y236, D256, W309, K369, D372, W399, and Q409 as key interacting amino acids with the natural substrate. The binding energy of the natural donor substrate will be used as the reference value here. 


\begin{tabular}{|l|l|l|}
\hline Compounds & $\begin{array}{l}\text { Binding energy } \\
(\mathbf{k c a l} / \mathbf{m o l})\end{array}$ & $\begin{array}{l}\text { Inhibition } \\
\text { constant, } \boldsymbol{\mu M}\end{array}$ \\
\hline Natural substrate & $-6.63 \pm 0.02$ & 14 \\
\hline $\mathbf{1 4}$ & $-4.18 \pm 0.01$ & 856 \\
\hline $\mathbf{1 5}$ & $-6.69 \pm 0.01$ & 12 \\
\hline $\mathbf{1 6}$ & $-6.83 \pm 0.01$ & 10 \\
\hline $\mathbf{1 7}$ & $-6.36 \pm 0.01$ & 21 \\
\hline $\mathbf{1 8}$ & $-5.02 \pm 0.01$ & 209 \\
\hline $\mathbf{1 9}$ & $-6.72 \pm 0.01$ & 12 \\
\hline
\end{tabular}

Table 3. Binding affinities and Inhibition constant $(\mathrm{T}=298.15 \mathrm{~K})$ of Imino-Sugars as GlfT2 inhibitors.

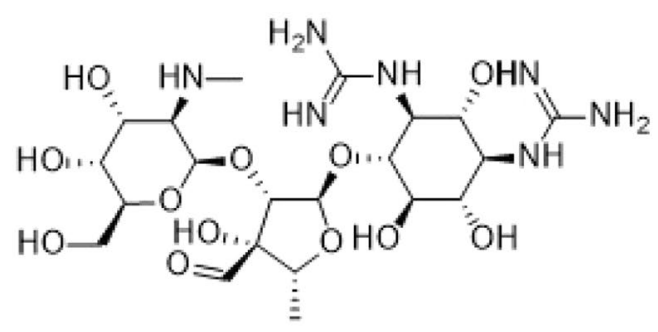

streptomycin

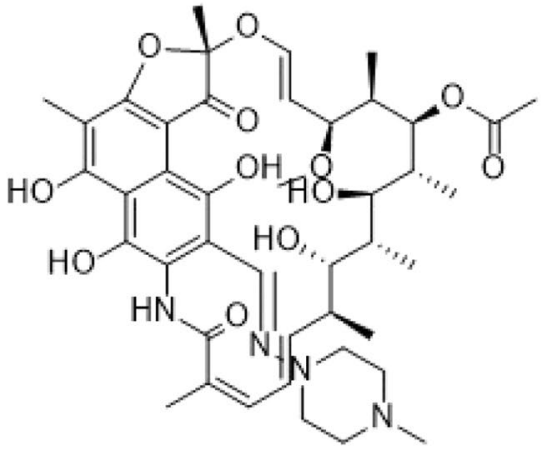

rifampicin<smiles>CCC(CO)NCCNC(CC)CO</smiles>

ethambutol<smiles>NNC(=O)c1ccncc1</smiles>

isoniazid<smiles>NC(=O)c1cnccn1</smiles>

pyrazinamide

Figure 4. Structures of the first-line Anti-TB drugs.

First line Anti-TB drug. Several anti-TB drugs developed were categorized according to target. One classification is the first-line anti-TB drugs (Fig. 4) which inhibits the synthesis of the bacterial cell wall essential for its pathogenicity ${ }^{41}$ and virulence ${ }^{42}$. The first-line anti-TB drug compounds were subjected to molecular docking studies. Results showed that the binding energy values indicate that these compounds weakly bind to the active site. Majority of the first-line anti-TB drugs such as ethambutol, isoniazid and pyrazinamide were found to have no interaction with the key GlfT2 active site amino acids (Table 2). Overall, the observed low binding energies of these compounds originated from the weak to lack of interaction with the amino acids within the active site (Table 1).

Current GIfT2 inhibitors in the literature. Recently, one of the strategies used to synthesized GlfT2 inhibitors is by mimicking the identified donor, acceptor, and transition-state substrates ${ }^{43-45}$. 
<smiles>O=c1ccn([C@@H]2O[C@H](CCP(=O)([O-])OP(=O)([O-])O[C@@H]3O[C@H]([C@@H](O)CF)[C@@H](O)[C@H]3O)[C@@H](O)[C@H]2O)c(=O)[nH]1</smiles><smiles></smiles><smiles>C[C@H](O)[C@H]1O[C@@H](OP(=O)([O-])OP(=O)([O-])CC[C@H]2O[C@@H](n3ccc(=O)[nH]c3=O)[C@H](O)[C@@H]2O)[C@H](O)[C@@H]1O</smiles><smiles>O=c1ccn([C@@H]2O[C@H](CCP(=O)([O-])OP(=O)([O-])O[C@@H]3O[C@H]([C@H](O)CCO)[C@@H](O)[C@H]3O)[C@@H](O)[C@H]2O)c(=O)[nH]1</smiles>

Figure 5. Structures of UDP-furanoses as GlfT2 inhibitors.

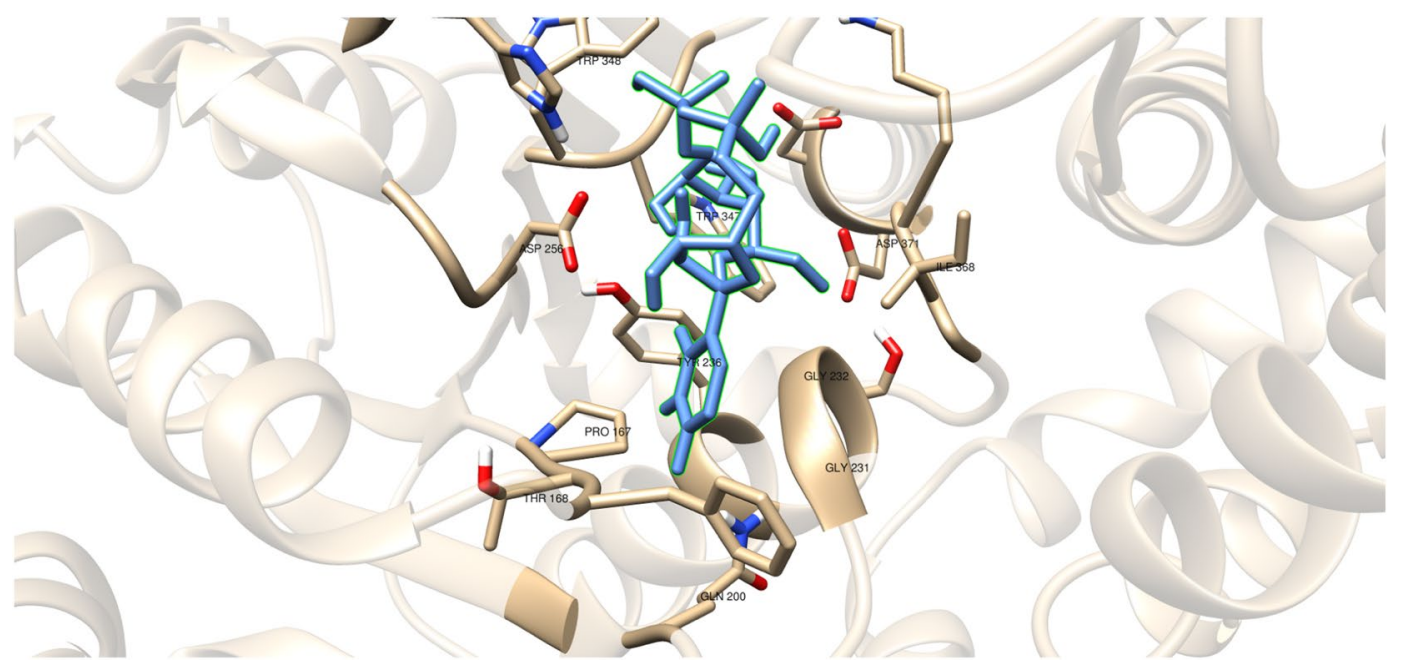

Figure 6. Three-dimensional plot of the interaction of compound \#49 with GlfT2's active site. 


\begin{tabular}{|c|c|c|c|c|c|c|c|c|c|c|c|c|c|c|c|c|c|c|}
\hline Compounds & Major & nteracti & g amino & acids & & & & & Addit & ional in & racting & mino ac & & & & & & \\
\hline Natural substrate & Y236 & D256 & W309 & W348 & K369 & D372 & W399 & Q409 & & & & & & & & & & \\
\hline 14 & Y236 & D256 & & W348 & & & & & P167 & R171 & & W347 & & & & & & \\
\hline 15 & Y236 & D256 & & W348 & & & & & P167 & R171 & G232 & W347 & I368 & & & & & \\
\hline 16 & Y236 & & & W348 & K369 & D372 & & & P167 & R171 & G232 & & & F169 & D371 & & & \\
\hline 17 & Y236 & D256 & & & K369 & D372 & & & P167 & & G232 & W347 & I368 & F169 & D371 & T168 & G231 & \\
\hline 18 & Y236 & D256 & & W348 & K369 & D372 & & & P167 & & G232 & W347 & & & D371 & & & \\
\hline 19 & Y236 & D256 & & W348 & K369 & D372 & & & P167 & R171 & G232 & W347 & I368 & F169 & D371 & & G231 & Q200 \\
\hline
\end{tabular}

Table 4. Interacting amino acids with Imino-Sugars as GlfT2 inhibitors.

\begin{tabular}{|l|l|l|}
\hline Compounds & $\begin{array}{l}\text { Binding energy } \\
(\mathbf{k c a l} / \mathbf{m o l})\end{array}$ & $\begin{array}{l}\text { Inhibition } \\
\text { constant, } \boldsymbol{\mu M}\end{array}$ \\
\hline Natural substrate & $-6.63 \pm 0.02$ & 14 \\
\hline $\mathbf{2 0}$ & $-5.80 \pm 0.01$ & 55 \\
\hline $\mathbf{2 1}$ & $-5.80 \pm 0.01$ & 55 \\
\hline $\mathbf{2 2}$ & $-5.98 \pm 0.01$ & 41 \\
\hline
\end{tabular}

Table 5. Binding affinities and Inhibition constant $(T=298.15 \mathrm{~K})$ of Sulfenamide and Sulfonamides as GlfT2 inhibitors.

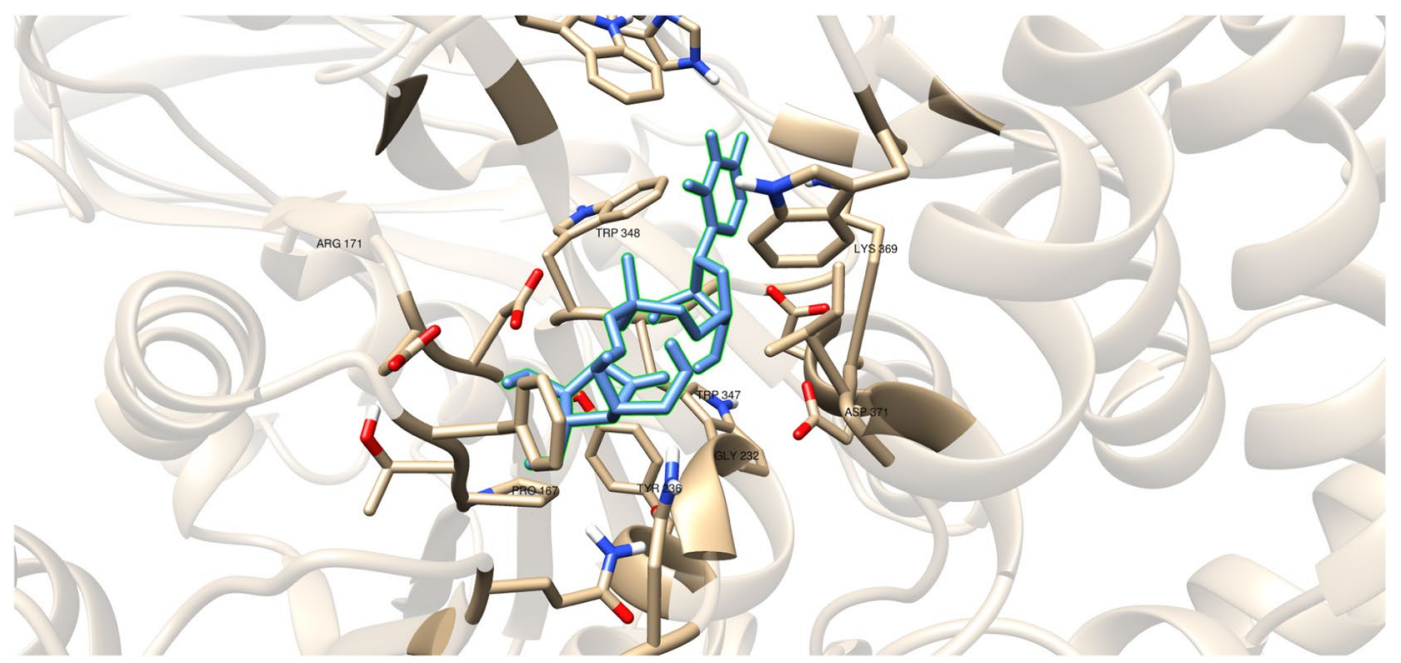

Figure 7. Three-dimensional plot of the interaction of compound 16 with GlfT2's active site.

Mimicking GlfT2's donor substrate as GlfT2 inhibitor. Compounds having a similar structure with the GlfT2's donor substrate could be used as potential GlfT2 inhibitors. In a previous study, donor substrate mimics such as compounds \#49-52 (Fig. 5) were examined using a spectrophotometric assay with GlfT1 and GlfT2. It was found that these compounds inhibit GlfT2 except for compound $\# 50^{16}$. Docking results showed that the binding energy values of compounds \#50 and \#52 (Fig. 5) were relatively lower than the reference value (Table 11). On the other hand, with respect to the reference value, compounds \#49 and \#51 (Fig. 5), exhibited lower binding energy values of $-6.79 \pm 0.03$ and $-6.72 \pm 0.10 \mathrm{kcal} \mathrm{mol}^{-1}$, respectively (Table 11). Furthermore, it showed that compounds $\# 49$, \#51, and \#52 interact with Y236, W348, P167, G232, and D371 (Fig. 6 and Table 12). Intriguingly, compound \#50 has lost its hydrophobic interaction with D256, I368, and T168. In contrary, these amino acids were found to interact with compounds \#49, \#51 and \#52 (Table 12). The absence of these amino acids interacting with compound \#50 could be the reason for its weak binding affinity with GlfT2 as described previously ${ }^{16}$.

As discussed previously, compounds \#15-19 were found to be UGM inhibitors and GlfT2 donor-substrate mimics (Fig. 4). Thus, all these compounds were subjected to molecular docking studies to probe whether the UGM inhibitors could also act as GlfT2 inhibitors. Results showed that the binding energy values of compounds $\# 15$, \#16 and \#19 were relatively higher than the reference value (Table 3). Compound \#17 was found to have a lower binding energy value of $-6.36 \pm 0.01 \mathrm{kcal} \mathrm{mol}^{-1}$ compared with the reference value. Compound \#18, compound \#17's analog, was found to have a binding energy value of $-5.02 \pm 0.01 \mathrm{kcal} \mathrm{mol}^{-1}$, relatively much lower compared with compound \#17. The absence of a UDP moiety in compound \#18, which was present in compound $\# 17$, could be the possible reason for its low binding affinity. The linker seems to increase the interaction of the 


\begin{tabular}{|c|c|c|c|c|c|c|c|c|c|c|c|c|c|c|c|c|c|c|c|c|}
\hline \multirow{2}{*}{\begin{tabular}{|l|} 
Compounds \\
$\begin{array}{l}\text { Natural } \\
\text { substrate }\end{array}$
\end{tabular}} & \multicolumn{8}{|c|}{ Major interacting amino acids } & \multicolumn{12}{|c|}{ Additional interacting amino acids } \\
\hline & Y236 & D256 & W309 & W348 & K369 & D372 & W399 & Q409 & & & & & & & & & & & & \\
\hline 20 & Y236 & D256 & & W348 & K369 & D372 & & & P167 & & G232 & W347 & & F169 & D371 & T168 & & & & \\
\hline 21 & Y236 & D256 & & & & D372 & & & P167 & R171 & G232 & W347 & & F169 & D371 & & G231 & Q200 & & \\
\hline 22 & Y236 & D256 & & W348 & & D372 & & & P167 & R171 & G232 & W347 & I368 & F169 & D371 & T168 & G231 & Q200 & G346 & W408 \\
\hline
\end{tabular}

Table 6. Interacting amino acids with Sulfenamide and Sulfonamides as GlfT2 inhibitors.

\begin{tabular}{|l|l|l|}
\hline Compounds & $\begin{array}{l}\text { Binding energy } \\
(\mathbf{k c a l} / \mathbf{m o l})\end{array}$ & $\begin{array}{l}\text { Inhibition } \\
\text { constant, } \boldsymbol{\mu M}\end{array}$ \\
\hline Natural substrate & $-6.63 \pm 0.02$ & 14 \\
\hline $\mathbf{2 3}$ & $-4.99 \pm 0.01$ & 217 \\
\hline $\mathbf{2 4}$ & $-5.31 \pm 0.01$ & 127 \\
\hline $\mathbf{2 5}$ & $-5.60 \pm 0.01$ & 78 \\
\hline
\end{tabular}

Table 7. Binding affinities and Inhibition constant $(\mathrm{T}=298.15 \mathrm{~K})$ of Transition State Mimics as GlfT2 inhibitors.

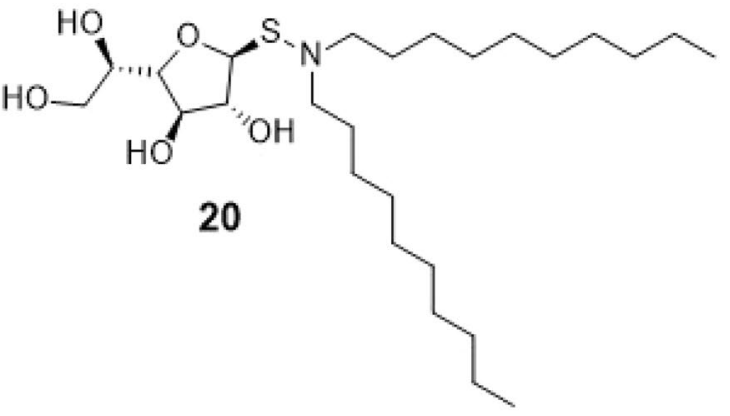

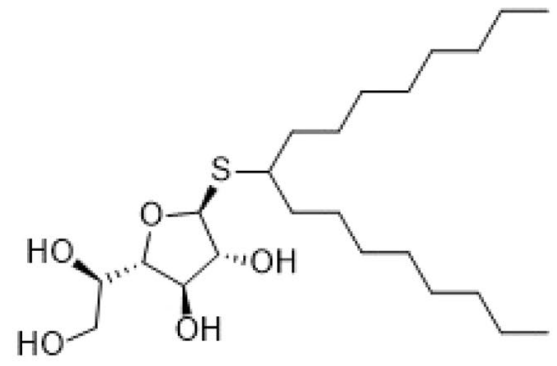

21

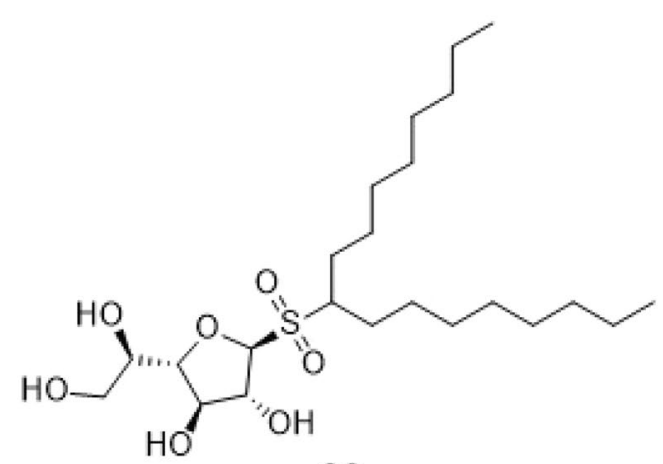

22

Figure 8. Structures of Sulfenamide and Sulfonamides as GlfT2 inhibitors.

ligand with the amino acid residues within the active site through hydrogen bonding. The interactions among the linker's phosphate group, Y236, and G232 were also observed with compounds \#15-17 and \#19. The presence of this kind of interaction could be the reason for the stabilization of these compounds within the active site (Fig. 7 and Table 4).

Mimicking GlfT2's acceptor substrate as GlfT2 inhibitor. Compounds \#20 (galactofuranosyl N,N'-didecyl sulfenamide), \#21 (galactofuranosyl dioctyl thioglycoside), and \#22 (sulfone derivative of compound \#21 via the oxidation of sulfur) (Fig. 8) were screened for inhibition effect using disk susceptibility test assay ${ }^{46}$. Results revealed that compound \#20 exhibited an inhibitory effect comparable to the shorter diakyl chains. On the other hand, compounds \#21 and \#22 were found to have an inhibitory effect with GlfT2 at a concentration less than $5 \mu \mathrm{M}^{46}$.

These compounds were subjected to molecular docking studies and showed lower binding energy values compared with the reference value (Table 5). Among these three, compound \#22 (Fig. 8) has highest binding energy 


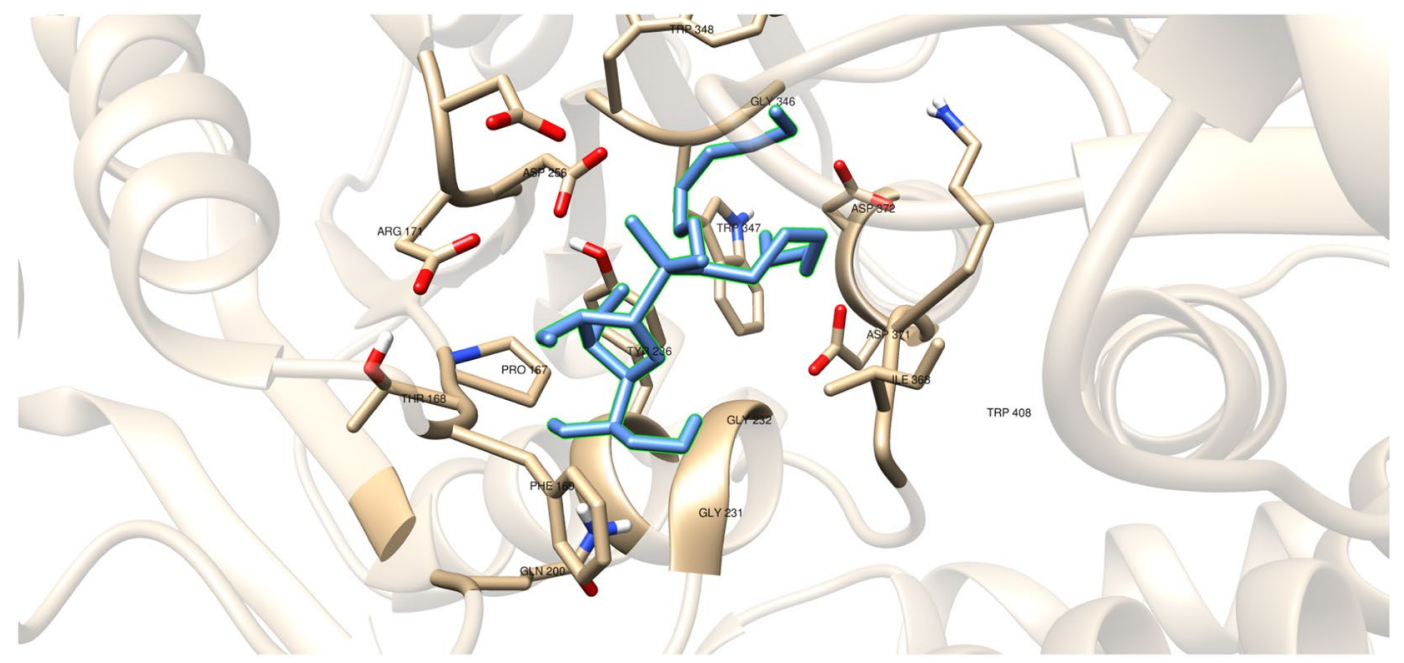

Figure 9. Three-dimensional plot of the interaction of compound \#22 with GlfT2's active site.

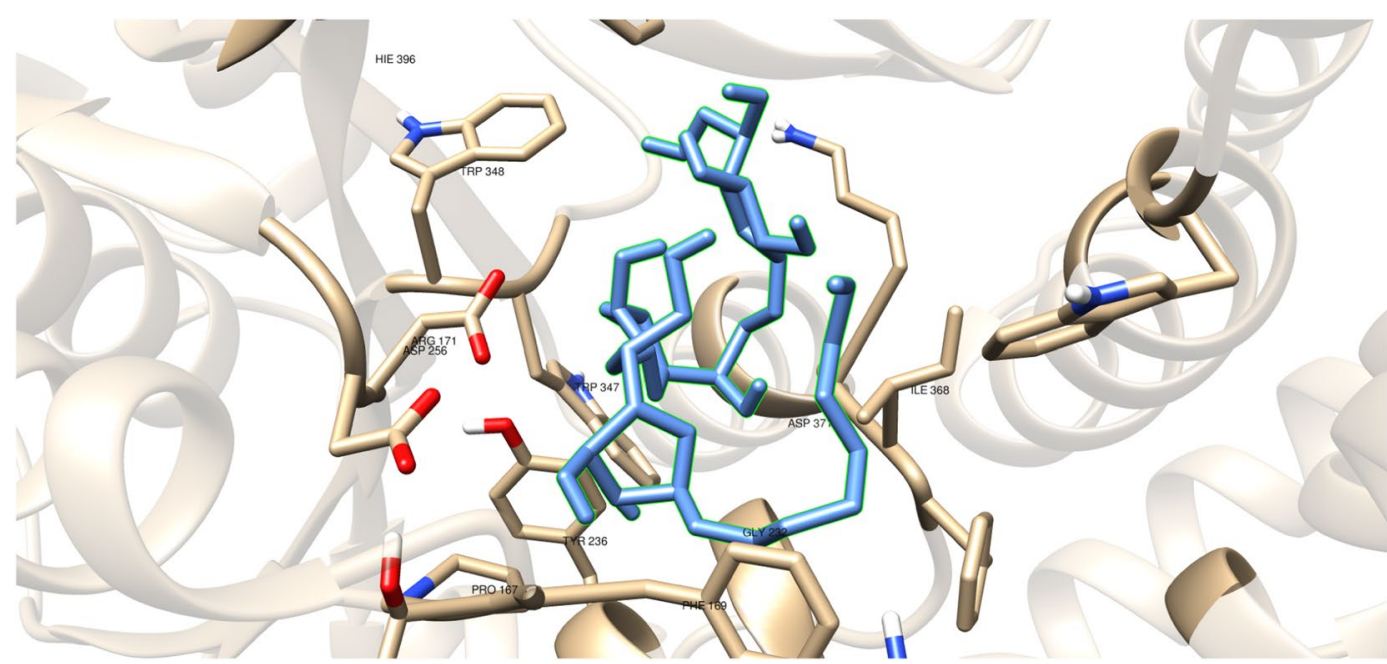

Figure 10. Three-dimensional plot of the interaction of compound \#55 with GlfT2's active site.

due to the additional oxygen (sulfone) that was observed to interact with D371 and D372 (Fig. 9). The dialkyls were observed to have hydrophobic interactions with R171, Y236, D371, D372, G232, W347, W348, and D256 (Table 6).

Compounds \#53-56 (Fig. 2) were synthesized to evaluate the specificity of Glf $\mathrm{T}^{16}$. Using kinetic characterization of GlfT with these compounds, it was found that trisaccharides were better substrates than disaccharides ${ }^{21}$. Docking studies were performed on these compounds and the results showed that trisaccharides, compounds \#55 and \#56, have lower binding energy values $\left(-6.24 \pm 0.04\right.$ and $-6.19 \pm 0.04 \mathrm{kcal} \mathrm{mol}^{-1}$, respectively) compared with disaccharides, compounds $\# 53$ and $\# 54\left(-6.16 \pm 0.03\right.$ and $-6.11 \pm 0.03 \mathrm{kcal} \mathrm{mol}^{-1}$, respectively) (Table 13). The additional sugar moiety of a trisaccharide compared to a disaccharide extended the long alkyl chain, allowing interaction with W408 via hydrophobic interaction (Fig. 10 and Table 14). This could be the origin of the enhanced interaction observed in both the experimental and docking studies.

UDP-Galactopyranose mutase (UGM) substrate as GlfT2 inhibitor. Another strategy used to inhibit GlfT2 was by repurposing compounds that were proposed to be inhibitors of enzymes involved in the galactan chain synthesis. One of these enzymes is UDP-Galactopyranose mutase (UGM). In the absence of galactofuranose in mammals ${ }^{33}$, UGM catalyzes the conversion of UDP-galactopyranose to UDP-galactofuranose which will eventually be the donor substrate of GlfT2 ${ }^{26,47}$. Here, some of the proposed UGM inhibitors were subjected to molecular docking studies with GflT2.

Compound \#14 (Fig. 1) was reported to be a weak inhibitor of UDP-Galp mutase $\mathrm{e}^{47}$. Upon molecular docking investigation the binding energy was found to be much lower, $-4.18 \pm 0.01 \mathrm{kcal} \mathrm{mol}^{-1}$, compared with the reference value (Table 3). Furthermore, among the key GlfT2 active site amino acids that were previously discussed, Y236, D256 and W348, were the only amino acids observed to be interacting with compound \#14. The decrease in the number of interacting amino acids with compound \#14 is one of the reasons for its poor binding affinity. 


\begin{tabular}{|l|l|l|l|l|l|l|l|l|l|l|l|l|l|l|l|l|l|l|l|l|}
\hline Com-pounds & \multicolumn{10}{|l|}{ Major interacting amino acids } & \multicolumn{10}{|c|}{ Additional interacting amino acids } \\
\hline $\begin{array}{l}\text { Natural } \\
\text { substrate }\end{array}$ & Y236 & D256 & W309 & W348 & K369 & D372 & W399 & Q409 & & & & & & & & & & & & \\
\hline $\mathbf{2 3}$ & Y236 & D256 & & W348 & & D372 & & & P167 & R171 & G232 & W347 & I368 & F169 & D371 & T168 & & & & \\
\hline $\mathbf{2 4}$ & Y236 & D256 & & & & D372 & & & P167 & R171 & G232 & W347 & & F169 & D371 & & G231 & Q200 & & \\
\hline $\mathbf{2 5}$ & Y236 & D256 & & W348 & & D372 & & & P167 & R171 & G232 & W347 & I368 & F169 & D371 & T168 & G231 & Q200 & G346 & W408 \\
\hline
\end{tabular}

Table 8. Interacting amino acids with Transition State Mimics as GlfT2 inhibitors.

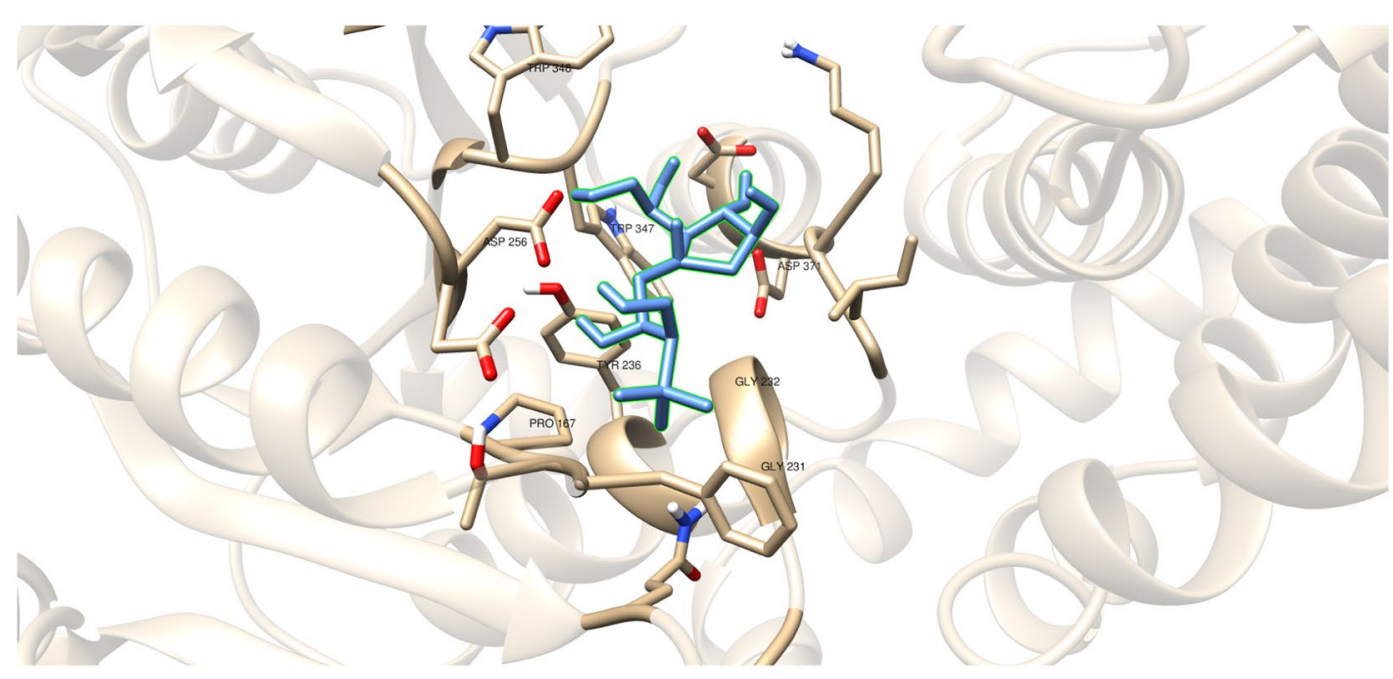

Figure 11. Three-dimensional plot of the interaction of compound \#25 with GlfT2's active site.

A recent study have discussed the development of microtiter plate-based assay to screen uridine-based compounds against $\mathrm{UGM}^{48}$. Among the compounds in the uridine-based library used in the assay, only compound \#27 (Fig. 12) was found to be a weak inhibitor $\left(\mathrm{IC}_{50}=6.0 \mu \mathrm{M}\right)$. Its binding energy value $\left(-8.32 \pm 0.01 \mathrm{kcal} \mathrm{mol}^{-1}\right)$ was observed to be lower than the reference value (Table 9). The interactions of the compound with P167, G232, W347, I368, D371, T168, W408, M285 and H296 may account for its improved binding affinity (Fig. 13).

Aside from being a known antibacterial agent for urinary tract infection treatment, compound \#28 (Fig. 12) was further used as a UGM inhibitor and found to moderately inhibit the enzyme ${ }^{49}$. Docking this with GlfT2 resulted in a lower binding energy compared with the reference value (Table 9). The absence of the interaction of this compound with W347, I368 and T168 may account for this lower binding affinity compared with compound \#27.

Compounds \#30 and \#31 showed a promising activity towards UGM $\left(\mathrm{IC}_{50}=1.6 \mu \mathrm{M}\right)^{50,51}$. These compounds differ in the type and number of halides they contain. Compound \#30 has only bromide and compound \#31 has two chloride and one iodide atom present in the 5-arylidene-2-thioxo-4-thiazolidinone (ATT) core. Results of the molecular docking studies showed that compound \#31 have a lower binding energy compared with compound \#30 (Table 9). The observed interaction of Q200 with compound \#30's chloride atom and K369 with iodide atom may account for the difference in the binding energy values between the two compounds (Table 10).

Compound \#29 (Fig. 12) showed no inhibition or poor inhibitory activity with $\mathrm{UGM}^{51}$. Molecular docking studies have found that it only registered a binding energy of $-3.96 \pm 0.01 \mathrm{kcal} \mathrm{mol}^{-1}$ which was much lower compared with the reference value. The derivative of the sugar moiety may have occupied only the sugar binding region of the active site and do not interact with the residues within the UDP binding region. This suggests that the residues interacting with UDP contribute to the binding of UDP-Galf, and the absence of UDP or replacement of any moiety that could mimic it, may account for the compound's low binding affinity.

Among the reported synthesized GlfT2 inhibitors that were included in this study, compounds \#27 and \#31 (Fig. 12) were found to have binding energies of $-8.32 \pm 0.01 \mathrm{kcal} \mathrm{mol}^{-1}$ and $-8.08 \pm 0.01 \mathrm{kcal} \mathrm{mol}^{-1}$, respectively (Tables 9 and 10). The observed higher binding energy values compared with GlfT2's natural substrate seems to originate from the interaction of W347, W348, and W408 (only for compound \#27) with the aromatic rings present in the compound. The presence of tryptophan within the active site could stabilize the inhibitors via $\pi-\pi$ interaction with the aromatic rings.

Mimicking GlfT2's transition-state substrate as GlfT2 inhibitor. Aside from mimicking the GlfT2 donor and acceptor substrates, mimicking the GlfT2 transition-state substrate (positively charged moiety) was another interesting strategy. Since $\alpha$-glycosidase and galactofuranosyltransferase carry out glycosyl transfer reaction, it was proposed that $\alpha$-glycosidase inhibitors could also be potential GflT2 inhibitors ${ }^{29}$. With this, molecular 


\begin{tabular}{|l|l|l|}
\hline Compounds & $\begin{array}{l}\text { Binding energy } \\
(\mathbf{k c a l} / \mathbf{m o l})\end{array}$ & $\begin{array}{l}\text { Inhibition } \\
\text { constant, } \boldsymbol{\mu M}\end{array}$ \\
\hline Natural substrate & $-6.63 \pm 0.02$ & 14 \\
\hline $\mathbf{2 7}$ & $-8.32 \pm 0.01$ & 1 \\
\hline $\mathbf{2 8}$ & $-7.13 \pm 0.01$ & 6 \\
\hline $\mathbf{2 9}$ & $-3.96 \pm 0.01$ & 1242 \\
\hline $\mathbf{3 0}$ & $-7.79 \pm 0.01$ & 2 \\
\hline $\mathbf{3 1}$ & $-8.08 \pm 0.01$ & 1 \\
\hline
\end{tabular}

Table 9. Binding affinities and Inhibition constant $(\mathrm{T}=298.15 \mathrm{~K})$ of Synthesized Halogenated GlfT2 inhibitors.<smiles>O=C(N/N=C/c1cc([N+](=O)[O-])cc([N+](=O)[O-])c1O)c1ccc(S(=O)(=O)CNC[C@H]2O[C@@H](n3ccc(=O)[nH]c3=O)[C@H](O)[C@@H]2O)cc1</smiles><smiles>COc1ccc(NC(=O)c2ccc([N+](=O)[O-])o2)cc1Cl</smiles><smiles>O=[PH](=O)([O-])CN[C@H](O)[C@H](O)[C@H](O)CO</smiles><smiles>O=C(O)[C@H](Cc1ccccc1)N1C/C(=C\c2ccc(Br)cc2)SC1=S</smiles>

30<smiles>O=C(O)[C@H](Cc1ccc(I)cc1)N1C/C(=C\c2ccc(Cl)c(Cl)c2)SC1=S</smiles>

31

Figure 12. Structures of UDP-Galactopyranose mutase (UGM) inhibitors as GlfT2 inhibitors.

docking studies using compounds $\# 23-25^{31}$ (Fig. 3) generate binding energies of $-4.99 \pm 0.01,-5.31 \pm 0.01$, and $-5.60 \pm 0.01 \mathrm{kcal} \mathrm{mol}^{-1}$, respectively (Table 7).

The positively charged moiety of these compounds were found to interact with D371 and the other interacting amino acids as shown in Fig. 11 and Table 8. Still, lower binding energy values were observed compared with the reference value (Table 7). The structural motif and binding energy values of compounds \#23-25 were comparable 


\begin{tabular}{|c|c|c|c|c|c|c|c|c|c|c|c|c|c|c|c|c|c|c|c|c|c|c|c|}
\hline \multirow{2}{*}{$\begin{array}{l}\text { Com-pounds } \\
\text { Natural } \\
\text { substrate }\end{array}$} & \multicolumn{8}{|c|}{ Major interacting amino acids } & \multicolumn{15}{|c|}{ Additional interacting amino acids } \\
\hline & Y236 & D256 & W309 & W348 & K369 & D372 & W399 & Q409 & & & & & & & & & & & & & & & \\
\hline 27 & Y236 & D256 & & W348 & & & & & P167 & & G232 & W347 & I368 & & D371 & T168 & & & & W408 & M285 & H396 & \\
\hline 28 & Y236 & & & & & D372 & & & P167 & R171 & G232 & & & F169 & D371 & & G231 & & & & & & \\
\hline 29 & Y236 & & & W348 & K369 & D372 & & & & & G232 & W347 & & & D371 & & & & & & & & \\
\hline 30 & Y236 & & & & & & & & P167 & & G232 & & I368 & F169 & & T168 & & & N229 & & & & F367 \\
\hline 31 & Y236 & & & W348 & & & & & P167 & & G232 & W347 & I368 & & & & G231 & Q200 & & & & & \\
\hline
\end{tabular}

Table 10. Interacting amino acids with synthesized halogenated compounds as GlfT2 inhibitors.

\begin{tabular}{|l|l|l|}
\hline Compounds & $\begin{array}{l}\text { Binding energy } \\
(\mathbf{k c a l} / \mathbf{m o l})\end{array}$ & $\begin{array}{l}\text { Inhibition } \\
\text { constant, } \boldsymbol{\mu M}\end{array}$ \\
\hline Natural substrate & $-6.63 \pm 0.02$ & 14 \\
\hline $\mathbf{4 9}$ & $-6.79 \pm 0.03$ & 10 \\
\hline $\mathbf{5 0}$ & $-6.57 \pm 0.03$ & 15 \\
\hline $\mathbf{5 1}$ & $-6.72 \pm 0.10$ & 12 \\
\hline $\mathbf{5 2}$ & $-6.42 \pm 0.03$ & 19 \\
\hline
\end{tabular}

Table 11. Binding affinities and Inhibition constant $(T=298.15 \mathrm{~K})$ of Synthetic UDP-furanoses.

with compound \#18. These compounds only have a sugar moiety and a short linker (Figs. 1 and 3 ). As previously discussed, the absence of a moiety that could interact with UDP binding region amino acids could account for the low binding affinity of a molecule within GlfT2's active site.

Newly Designed Sugar Furanosides as GlfT2 Inhibitors. In silico drug design draws attention among researches because it is time-saving and cheap. Computer-aided drug design uses computational tools to discover, develop, and analyze drugs ${ }^{52}$. One technique used for drug design is ligand-based computer-aided drug design which involves ligands that are known to interact with target receptor, and account for the binding strength of a given molecule by knowing the nature of the interactions ${ }^{53}$.

Functionalizing a drug with an azide group has been largely used in the pharmaceutical industries ${ }^{54,55}$. It was then recognized as a novel pharmacophore in medicinal chemistry especially in the emergence of zidovudine, an anti-retroviral drug for the treatment of Acquired Immuno-Deficiency Syndrome (AIDS). Also, azide group was used in tumor-labelling ${ }^{56}$ for cancer treatment. It is noteworthy that azido-substituted drugs have high affinity towards the target receptor ${ }^{57}$. It was found that tetrahydroimidazobenzodiazepinthiones (TIBO) or thiourea derivatives are potential drugs for treating $\mathrm{TB}^{58,59}$. Guanidine derivative drugs also pose a promising

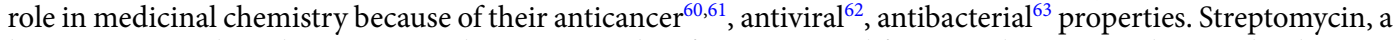
known anti-TB drug, has two guanidino groups. The aforementioned functional groups such as azido, thiourea and guanidino groups were used here in designing new GlfT2 inhibitors because of their antibacterial property and high receptor affinity.

The design was an analog of the known GlfT2 substrate dissacharide, octyl $\beta$-D-galactofuranosyl- $(1 \rightarrow 5)$ $\beta$-L-arabino-furanoside. They found that substrates with longer chain aglycon were better substrates of glycosyltransferases in Mycobacterium species ${ }^{64}$. Compounds \#2 and \#3 (Fig. 14) were both trans-2-tridecen-1-yl glycosides having a modification in the non-reducing end wherein the 6-OH position was replaced with azido and thiourea functional groups, respectively. On the other hand, compound \#1 was obtained via the oxidation of double bond in the aglycon of compound \#3. It was found that compound \#3 has a higher binding energy value of $-10.32 \pm 0.02 \mathrm{kcal} \mathrm{mol}^{-1}$ compared with compound $\# 2$ with binding energy value of $-11.08 \pm 0.02 \mathrm{kcal} \mathrm{mol}^{-1}$. It is proposed that the presence of azido group have a higher binding affinity compared with the thiourea group which is evident on the binding energies presented.

From the binding energies of compounds \# 1 and \#3, it can be observed that compound \# 1 has a lower binding energy of $-14.67 \pm 0.04 \mathrm{kcal} \mathrm{mol}^{-1}$ compared with compound $\# 3$ having $-10.32 \pm 0.02 \mathrm{kcal} \mathrm{mol}^{-1}$ (Table 15). There were observed interactions among D256,Y236, and thiourea and another set of interactions among D371, D372, the hydroxyl groups of the disaccharide, and the aglycon of compound \#1 (Table 16). The addition of two hydroxyl groups on the aglycon effectively increased the enzyme-substrate interaction within the active site.

Compound \#4 (Fig. 14), a glyceryl glycoside, has a modification in the non-reducing end wherein the 5-OH and 6- $\mathrm{OH}$ position were replaced with an azido and guanidino functional groups, respectively. As observed, D256 and I368 interacts with the hydroxyl groups of glyceryl aglycon (Table 16). Y344, P167 and D258 were observed to interact with the guanidino group and D372 was observed to interact with the azide group (Fig. 15 and Table 16). These residues interact with the inhibitor through hydrogen bonding and seem to be the origin for the observed high binding affinity. Among the newly designed sugar-based inhibitors, compound \#4 is the most promising compound with a binding energy of $-19.23 \pm 0.05 \mathrm{kcal} \mathrm{mol}^{-1}$. 


\begin{tabular}{|l|l|l|l|l|l|l|l|l|l|l|l|l|l|l|l|l|}
\hline Compounds & \multicolumn{4}{l|}{ Major interacting amino acids } & \multicolumn{4}{l|}{ Additional interacting amino acids } \\
\hline Natural substrate & Y236 & D256 & W309 & W348 & K369 & D372 & W399 & Q409 & & & & & & & & \\
\hline $\mathbf{4 9}$ & Y236 & D256 & & W348 & & & & & P167 & & G232 & W347 & I368 & F169 & D371 & T168 \\
\hline $\mathbf{5 0}$ & Y236 & & & W348 & & D372 & & & P167 & R171 & G232 & & & & D371 & \\
\hline $\mathbf{5 1}$ & Y236 & D256 & & W348 & K369 & D372 & & & P167 & & G232 & W347 & I368 & & D371 & T168 \\
\hline $\mathbf{5 2}$ & Y236 & D256 & & W348 & K369 & D372 & & & P167 & & G232 & W347 & I368 & & D371 & T168 \\
\hline
\end{tabular}

Table 12. Interacting amino acids with Synthetic UDP-furanoses as GlfT2 inhibitors.

\begin{tabular}{|l|l|l|}
\hline Compounds & $\begin{array}{l}\text { Binding energy } \\
(\mathbf{k c a l} / \mathbf{m o l})\end{array}$ & $\begin{array}{l}\text { Inhibition } \\
\text { constant, } \boldsymbol{\mu M}\end{array}$ \\
\hline Natural substrate & $-6.63 \pm 0.02$ & 14 \\
\hline $\mathbf{5 3}$ & $-6.16 \pm 0.03$ & 30 \\
\hline $\mathbf{5 4}$ & $-6.11 \pm 0.03$ & 33 \\
\hline $\mathbf{5 5}$ & $-6.24 \pm 0.04$ & 26 \\
\hline $\mathbf{5 6}$ & $-6.19 \pm 0.04$ & 29 \\
\hline
\end{tabular}

Table 13. Binding affinities and Inhibition constant $(T=298.15 \mathrm{~K})$ of Synthetic Acceptor Substrates.

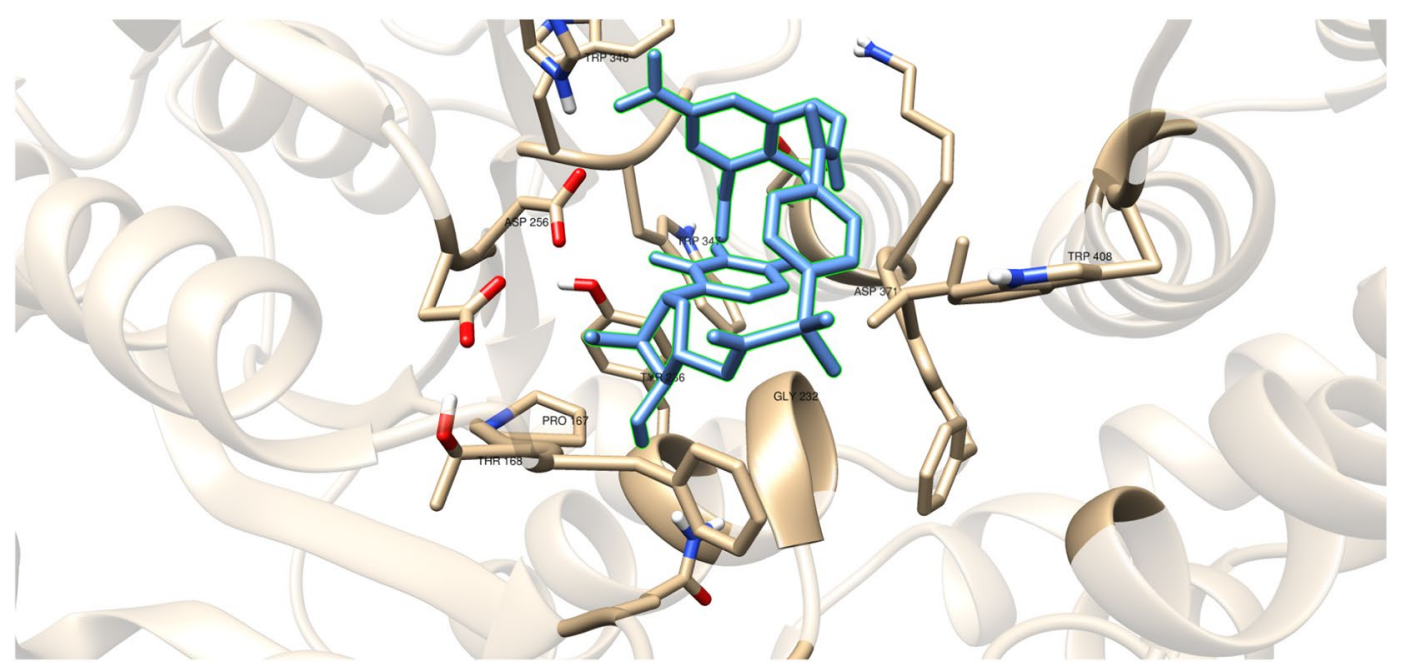

Figure 13. Three-dimensional plot of the interaction of compound \#27 with GlfT2's active site.

Redesigned Sugar Furanosides as GlfT2 Inhibitors using 3D-QSAR. Structures of the synthesized GlfT2 inhibitors were subjected to 3D-QSAR to improve the structural motif of the inhibitors. The 3D-QSAR is an important tool on providing substantial information about the molecular attribute essential for biological activity of compounds ${ }^{65,66}$.

Results showed that the Pearson coefficient is $\mathrm{R}^{2}=0.99$ which signifies the reliability of the test and training sets used. The structures of the presented synthesized GlfT2 inhibitors were aligned along their respective molecular field points. Figure 20 shows negative steric field points (green field) which indicate that steric groups should be avoided on that particular part of the molecule. Whereas, positive steric field points (yellow field) indicate that steric groups should be added on that particular part of the molecule. Moreover, negative electrostatic field points indicate that an electrostatic contributor i.e. negatively charged group/hydrogen-bond acceptor, should be added on that particular part of the molecule. Whereas, positive electrostatic field points indicate that an electrostatic contributor i.e. positively charged group/hydrogen-bond donor, should be added on that particular part of the molecule.

From this, insights on designing the top 18 hit compounds were acquired. From 3D-QSAR, instead of having a flexible long chain aglycon, the aglycon was replaced with cholesterol (compound \#58), tocopherol (compound \#62), retinol (compound \#61) cholesterol derivatives i.e. calciferol, calcitriol (compound \#63), cholecalciferol (compounds \#59, \#60 and \#64) and cholecalciferol derivatives (compounds \#66-75) which are more rigid and sterically hindered.

The 5-OH and 6-OH position of the non-reducing end of the substrates were functionalized with azido- and guanidino-group, respectively for compounds \#58 and \#59 (Figs. 16 and 17). For compounds \#66-75 (Figs. 16 and 17), the $5-\mathrm{OH}$ and $6-\mathrm{OH}$ position of the non-reducing end of the substrates were functionalized with amine- and 


\begin{tabular}{|c|c|c|c|c|c|c|c|c|c|c|c|c|c|c|c|c|c|c|c|c|c|}
\hline \multirow{2}{*}{$\begin{array}{l}\begin{array}{l}\text { Com- } \\
\text { pounds }\end{array} \\
\begin{array}{l}\text { Natural } \\
\text { substrate }\end{array}\end{array}$} & \multicolumn{8}{|c|}{ Major interacting amino acids } & \multicolumn{13}{|c|}{ Additional interacting amino acids } \\
\hline & Y236 & D256 & W309 & W348 & K369 & D372 & W399 & Q409 & & & & & & & & & & & & & \\
\hline 53 & Y236 & D256 & & W348 & & D372 & & & P167 & & G232 & W347 & I368 & F169 & D371 & & G231 & Q200 & & & N229 \\
\hline 54 & Y236 & D256 & & & K369 & D372 & & & P167 & & G232 & W347 & I368 & F169 & D371 & T168 & G231 & & & H396 & \\
\hline 55 & Y236 & D256 & & W348 & K369 & & & & P167 & R171 & G232 & W347 & I368 & F169 & D371 & & & & W408 & & \\
\hline 56 & Y236 & D256 & & W348 & K369 & \begin{tabular}{|l|} 
D372 \\
\end{tabular} & & & \begin{tabular}{|l|} 
P167 \\
\end{tabular} & & G232 & W347 & I368 & & & & G231 & & W408 & & \\
\hline
\end{tabular}

Table 14. Interacting amino acids with Synthetic Acceptor Substrates as GlfT2 inhibitors.

\begin{tabular}{|l|l|l|}
\hline Compounds & $\begin{array}{l}\text { Binding energy } \\
(\mathbf{k c a l} / \mathbf{m o l})\end{array}$ & $\begin{array}{l}\text { Inhibition } \\
\text { constant, } \boldsymbol{\mu M}\end{array}$ \\
\hline Natural substrate & $-6.63 \pm 0.02$ & 14 \\
\hline $\mathbf{1}$ & $-14.67 \pm 0.04$ & $1.71 \times 10-4$ \\
\hline $\mathbf{2}$ & $-11.08 \pm 0.02$ & $1.95 \times 10-3$ \\
\hline $\mathbf{3}$ & $-10.32 \pm 0.02$ & $2.7 \times 10-1$ \\
\hline $\mathbf{4}$ & $-19.23 \pm 0.05$ & $7.7 \times 10-9$ \\
\hline
\end{tabular}

Table 15. Binding affinities and Inhibition constant $(\mathrm{T}=298.15 \mathrm{~K})$ of newly designed GlfT2 inhibitors.

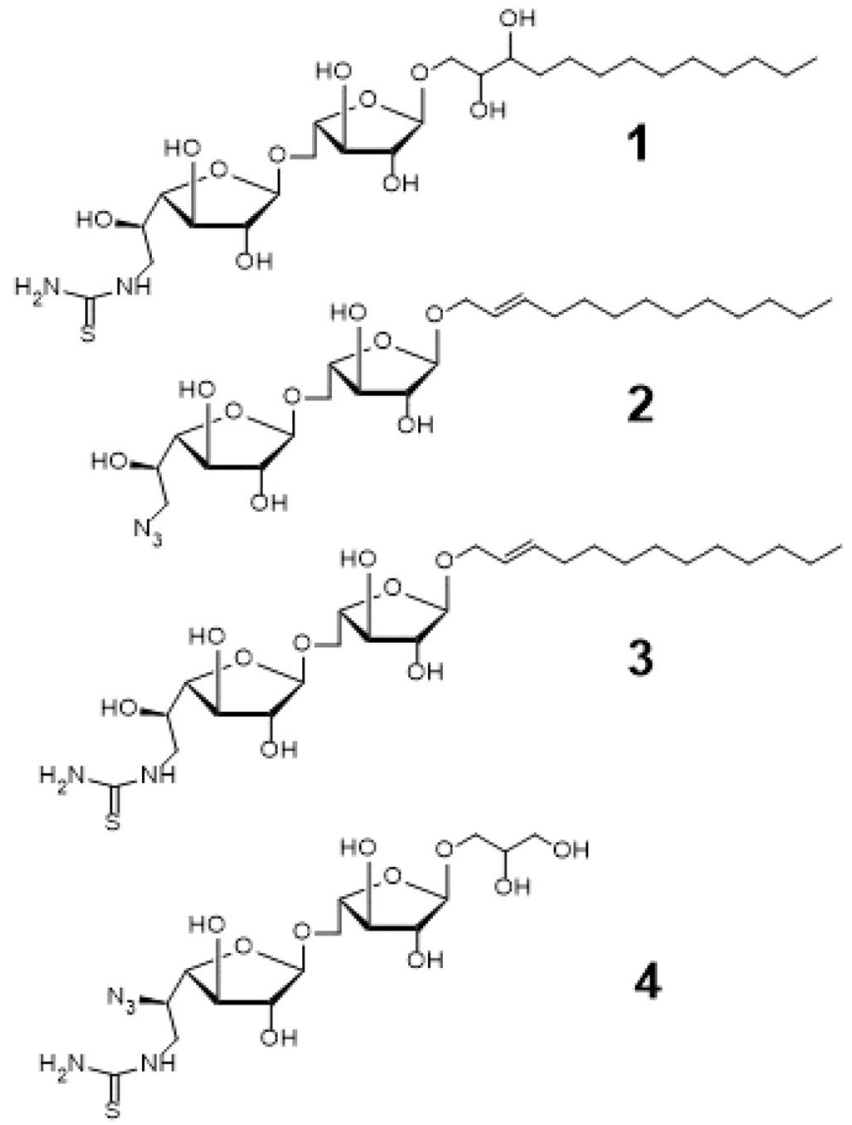

Figure 14. Structures of Newly Designed Acceptor Substrates as GlfT2 inhibitors.

methyl group. For compounds \#60-63 and \#65 (Figs. 16 and 17), only 6-OH position of the non-reducing end of the substrates were functionalized with a methyl group. Lastly, for compound \#64 (Fig. 16), the 6-OH position of its non-reducing end was functionalized with a thiourea group. 


\begin{tabular}{|c|c|c|c|c|c|c|c|c|c|c|c|c|c|c|c|c|c|c|c|c|c|c|}
\hline \multirow{2}{*}{\begin{tabular}{|l|}
$\begin{array}{l}\text { Com- } \\
\text { pounds }\end{array}$ \\
$\begin{array}{l}\text { Natural } \\
\text { substrate }\end{array}$
\end{tabular}} & \multicolumn{8}{|c|}{ Major interacting amino acids } & \multicolumn{14}{|c|}{ Additional interacting amino acids } \\
\hline & Y236 & D256 & W309 & W348 & K369 & D372 & W399 & Q409 & & & & & & & & & & & & & & \\
\hline 1 & Y236 & D256 & & W348 & & D372 & & & P167 & & G232 & W347 & I368 & F169 & D371 & & G231 & Q200 & & & & \\
\hline 2 & Y236 & D256 & & W348 & K369 & D372 & & & P167 & & G232 & W347 & I368 & F169 & D371 & T168 & G231 & & & & & H396 \\
\hline 3 & Y236 & D256 & & W348 & K369 & D372 & & & P167 & R171 & G232 & W347 & I368 & F169 & D371 & & & & & W408 & & \\
\hline 4 & Y236 & D256 & & W348 & K369 & D372 & & & P167 & & G232 & W347 & I368 & & & & G231 & & D258 & W408 & Y344 & \\
\hline
\end{tabular}

Table 16. Interacting amino acids with Newly Designed Acceptor Substrates as GlfT2 inhibitors.

\begin{tabular}{|l|l|l|}
\hline Compounds & $\begin{array}{l}\text { Binding energy } \\
(\mathbf{k c a l} / \mathbf{m o l})\end{array}$ & $\begin{array}{l}\text { Inhibition } \\
\text { constant, } \boldsymbol{\mu M}\end{array}$ \\
\hline Natural substrate & $-6.63 \pm 0.02$ & 14 \\
\hline $\mathbf{5 8}$ & $-8.28 \pm 0.05$ & 1 \\
\hline $\mathbf{5 9}$ & $-8.29 \pm 0.05$ & 1 \\
\hline $\mathbf{6 0}$ & $-8.35 \pm 0.05$ & 1 \\
\hline $\mathbf{6 1}$ & $-8.24 \pm 0.05$ & 1 \\
\hline $\mathbf{6 2}$ & $-8.10 \pm 0.06$ & 1 \\
\hline $\mathbf{6 3}$ & $-8.21 \pm 0.05$ & 1 \\
\hline $\mathbf{6 4}$ & $-8.08 \pm 0.04$ & 1 \\
\hline $\mathbf{6 5}$ & $-7.64 \pm 0.05$ & 2 \\
\hline
\end{tabular}

Table 17. Binding affinities and Inhibition constant $(T=298.15 \mathrm{~K})$ of $3 \mathrm{D}-\mathrm{QSAR}$ designed compounds.

These 18 newly 3D-QSAR designed structures, compounds \#58-75 (Figs. 16 and 17) were subjected to ensemble docking to reassess the binding affinity of the compounds. The compounds registered binding energy values of $\sim-8.00 \mathrm{kcal} \mathrm{mol}^{-1}$ from having a binding energy values of $\sim-6.00 \mathrm{kcal} \mathrm{mol}^{-1}$ (Tables 17 and 19).

Results show that the modification of the aglycon instead of the sugar moiety lead to the significant increase on the binding energy of designed compounds.

Additional amino acids were found to be interacting with these compounds as shown in Tables 18 and 20. It can be seen that compounds \#63-65 were found to be interacting with both M286 and K402 through hydrogen bonding (Figs. 18 and 19). These interactions were also observed between compound \#59 and K402, and between compounds \#68 and \#75 and M286 (Figs. 18 and 19).

Structure-activity relationship representation. Various designs of the possible GlfT2 inhibitors are summarized in Fig. 21 using a Structure-Activity Relationship (SAR) representation. This shows the effect of the different R-groups added to the pharmacophore of the QSAR-based, Donor substrate-based and Acceptor substrate-based compounds on their activity. To design for possible GlfT2 inhibitors, the compound should have at least one sugar moeity (D-Galf) provided that the 5-OH and/or 6-OH position have R-groups that could disrupt the compounds' hydrogen-bond interaction with D372 (Figure 18). In addition, the presence of a UDP or UDP-like moiety (long alkyl chain or steriodal aglycon) could possibly increase the binding affinity of the compound.

ADMETox evaluation of the best candidates. The predicted ADME part of this study was carried out using an online server, SwissADME ${ }^{67}$, that gives values for lipophilicity, water solubility, drug-likeness, medicinal chemistry (i.e. leadlikeness, and PAINS and Breck). Whereas, in silico toxicity evaluation was carried out also using an online server, ProTox-II ${ }^{68}$, that gives predicted oral toxicity values, predicted cytotoxicity, mutagenicity, carcinogenicity, hepatotoxicity, and immunotoxicity. In addition, ProTox-II also gives an overview whether the compounds being analyzed will bind to the proteins known to produce adverse reaction to drugs.

Drug-likeness, bioavailability, synthetic accessibility and alerts for PAINS and Brenk filters. Drug-likeness is a quantitative parameter that measures a compound's oral bioavailability. Abbot bioavailability score predicts the chance of a compound to have at least $10 \%$ oral bioavailability in rat or measurable Caco- 2 cell line permeability experiment. This permeability experiment use Caco-2 cells as a model for human intestinal absorption of drugs ${ }^{69}$. The parameters considered to measure the score are lipophilicity $(-0.7<$ XLOGP3 $<5.0)$, molecular weight (MW) $\left(150 \mathrm{~g} \mathrm{~mol}^{-1}<\mathrm{MW}<500 \mathrm{~g} \mathrm{~mol}^{-1}\right)$, polarity $\left(20 \AA^{2}<\mathrm{TPSA}<130 \AA^{2}\right)$, solubility $(0<\log \mathrm{S}(\mathrm{ESOL})<6)$, saturation $(0.25<$ Fraction Csp $3<1)$ and flexibility $(0<$ of rotatable bonds $<9)$. This semi-quantitative rule-based score defines the compounds into four probability score classes i.e $11 \%, 17 \%, 55 \%$ and $85 \%{ }^{69,70}$. The acceptable probability score is $55 \%$ which indicates that it passed the rule of five. Among the top hits, compounds $\# 31, \# 60, \# 61, \# 62, \# 66, \# 67, \# 71, \# 72, \# 73, \# 74$ and \#75 showed a score of $55 \%$, indicating good bioavailability.

PAINS (Pan Assay Interference compounds) and Brenk $k^{71}$ method are used to identify potentially problematic molecular fragments that could give false-positive biological activity output ${ }^{65,69}$. Thus, the PAINS and Brenk 


\begin{tabular}{|c|c|c|c|c|c|c|c|c|c|c|c|c|c|c|c|c|c|c|c|c|c|c|c|}
\hline \multirow{2}{*}{\begin{tabular}{|l|} 
Compounds \\
$\begin{array}{l}\text { Natural } \\
\text { substrate }\end{array}$
\end{tabular}} & \multicolumn{8}{|c|}{ Major interacting amino acids } & \multicolumn{15}{|c|}{ Additional interacting amino acids } \\
\hline & Y236 & D256 & W309 & W348 & K369 & D372 & W399 & Q409 & & & & & & & & & & & & & & & \\
\hline 58 & & D256 & W348 & K369 & & & & & G232 & W347 & I368 & F169 & & & G231 & & H396 & & & & & & \\
\hline 59 & Y236 & D256 & W348 & K369 & D372 & Q409 & P167 & R171 & G232 & W347 & I368 & F169 & & & & Q200 & & & & K402 & Y348 & & \\
\hline 60 & Y236 & D256 & & & D372 & & & & G232 & W347 & I368 & F169 & D371 & T168 & & Q200 & H396 & & & & & Y344 & W309 \\
\hline 61 & Y236 & & W348 & K369 & D372 & & & & & W347 & & & & & & & & E300 & & & & & \\
\hline 62 & Y236 & & W348 & K369 & D372 & Q409 & P167 & & & W347 & I368 & & D371 & & & & & E300 & & & & & \\
\hline 63 & Y236 & D256 & W348 & K369 & D372 & & P167 & R171 & G232 & W347 & I368 & F169 & D371 & T168 & G231 & Q200 & H396 & & M286 & K402 & & & \\
\hline 64 & Y236 & D256 & W348 & K369 & & & & R171 & & & & F169 & D371 & T168 & & Q200 & H396 & E300 & M286 & K402 & & & \\
\hline 65 & Y236 & D256 & W348 & K369 & & & P167 & & G232 & W347 & & & D371 & & & & & & M286 & K402 & & & \\
\hline
\end{tabular}

Table 18. Interacting amino acids with $3 \mathrm{D}-\mathrm{QSAR}$ designed compounds.

\begin{tabular}{|l|l|l|}
\hline Compounds & $\begin{array}{l}\text { Binding energy } \\
(\mathbf{k c a l} / \mathbf{m o l})\end{array}$ & $\begin{array}{l}\text { Inhibition } \\
\text { constant, } \boldsymbol{\mu M}\end{array}$ \\
\hline Natural substrate & $-6.63 \pm 0.02$ & 14 \\
\hline $\mathbf{6 6}$ & $-8.47 \pm 0.05$ & 1 \\
\hline $\mathbf{6 7}$ & $-8.36 \pm 0.06$ & 1 \\
\hline $\mathbf{6 8}$ & $-8.41 \pm 0.04$ & 1 \\
\hline $\mathbf{6 9}$ & $-8.23 \pm 0.05$ & 1 \\
\hline $\mathbf{7 0}$ & $-8.51 \pm 0.05$ & 1 \\
\hline $\mathbf{7 1}$ & $-8.21 \pm 0.05$ & 1 \\
\hline $\mathbf{7 2}$ & $-8.28 \pm 0.05$ & 1 \\
\hline $\mathbf{7 3}$ & $-8.17 \pm 0.05$ & 1 \\
\hline $\mathbf{7 4}$ & $-8.69 \pm 0.05$ & 1 \\
\hline $\mathbf{7 5}$ & $-8.67 \pm 0.05$ & 1 \\
\hline
\end{tabular}

Table 19. Binding affinities and Inhibition constant $(T=298.15 \mathrm{~K})$ of $3 \mathrm{D}-\mathrm{Q} S A R$ designed compounds.

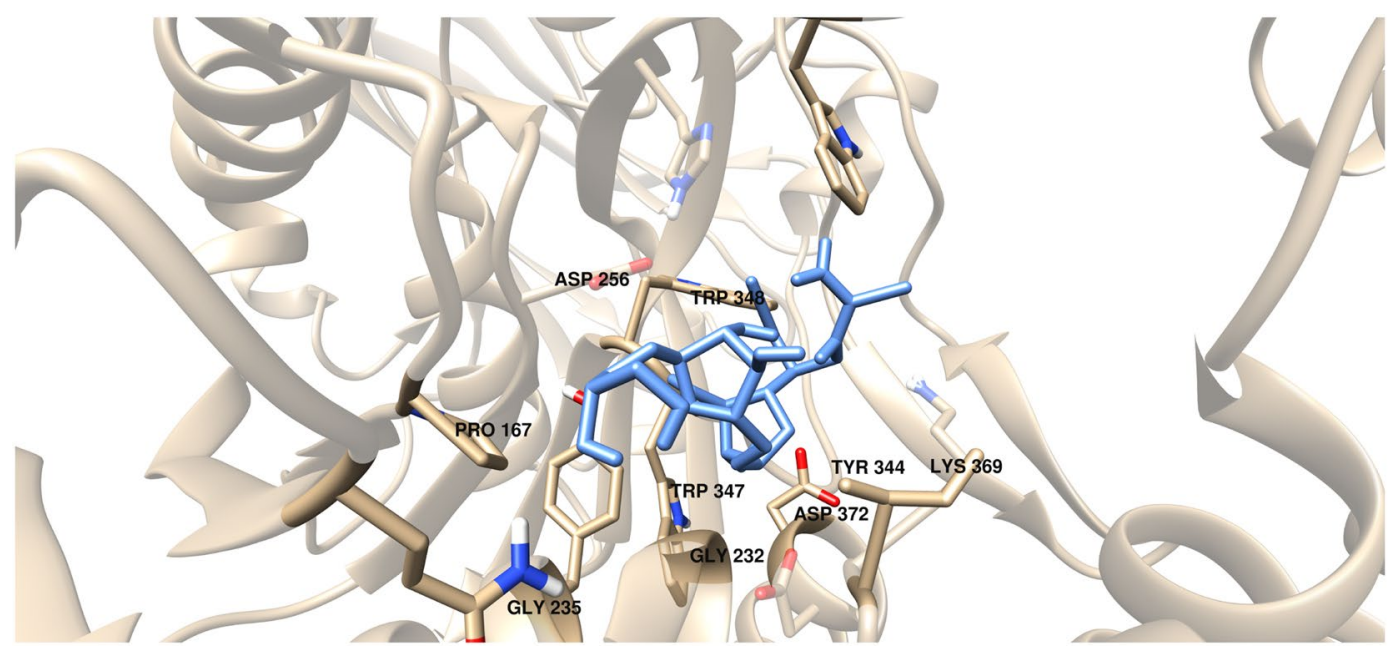

Figure 15. Three-dimensional plot of the interaction of compound \#4 with GlfT2's active site.

screening showed that compounds having the following functional groups: (1) imine- and azo- fragments i.e

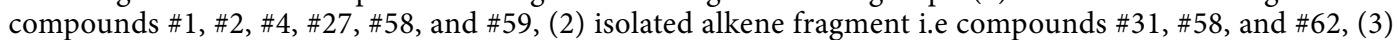
thiocarbonyl fragment i.e compounds \#3 and \#64, and (4) polyene fragment i.e compound \#61 (Table 21). The remaining compounds showed no problematic chemical fragments.

Lead-likeness of a compound is predicted using parameters such as $\mathrm{MW}\left(250 \mathrm{~g} \mathrm{~mol}^{-1} \leq \mathrm{MW} \leq 350 \mathrm{~g} \mathrm{~mol}^{-1}\right)$, octanol/water partition coefficients $(X L O G P \leq 3.5)$ and number of rotatable bonds (\# rotatable bonds $\leq 7$ ). Results showed that none of the top hit compounds fall within the set criteria. To quantify the complexity of the molecular structure, synthetic accessibility was assessed. The results showed that the scores for the compounds 


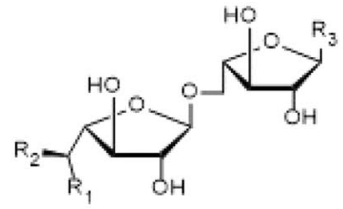

$$
\begin{aligned}
& \mathbf{R}_{1}=\mathrm{H}_{2} \mathrm{~N}_{\mathrm{NH}_{2}}^{\mathrm{NH}} \\
& \mathrm{R}_{2}=\mathrm{N}_{3} \\
& \mathrm{R}_{3}=\mathrm{A} 3
\end{aligned}
$$

58<smiles>[R2][R]#N</smiles>

59
$\mathbf{R}_{\mathbf{1}}=\mathrm{CH}_{3}$
$\mathbf{R}_{2}=\mathrm{OH}$
$\mathbf{R}_{3}=\mathrm{A} 1$

60

$$
\begin{aligned}
& \mathbf{R}_{1}=\mathrm{CH}_{3} \\
& \mathbf{R}_{2}=\mathrm{OH}
\end{aligned}
$$$$
R_{3}=A 2
$$

61

$\begin{array}{llll}\mathbf{R}_{1}=\mathrm{CH}_{3} & \mathbf{R}_{1}=\mathrm{CH}_{3} & \mathbf{R}_{\mathbf{1}}=\mathrm{H}_{2} \mathrm{~N} N \mathrm{NH}_{2} & \mathbf{R}_{1}=\mathrm{CH}_{3} \\ \mathbf{R}_{2}=\mathrm{OH} & \mathbf{R}_{2}=\mathrm{OH} & \mathbf{R}_{2}=\mathrm{OH} & \mathbf{R}_{2}=\mathrm{OH} \\ \mathbf{R}_{3}=\mathrm{A} 4 & \mathbf{R}_{3}=\mathrm{AS} & \mathbf{R}_{3}=\mathrm{A} 1 & \mathbf{R}_{3}=\mathrm{AS}\end{array}$

62
63
64<smiles>C=C1CC[C@@H](OC(C)(C)C)C/C1=C/C=C1\CCCC2(C)C1CCC2[C@@H](C)CCCC(C)C</smiles>

A1<smiles>CC(C)CCC[C@H](C)[C@H]1CC[C@H]2[C@@H]3CC=C4C[C@@H](OC(C)(C)C)CC[C@]4(C)[C@H]3CC[C@]21C</smiles>

A3<smiles>C=C1/C(=C/C=C2\CCCC3(C)C2CCC3[C@@H](C)CCCC(O)(O)O)CC(OCC)CC1O</smiles>

A5<smiles>CCOC/C=C(C)/C=C/C=C(C)/C=C/C1=C(C)CCCC1(C)C</smiles>

A2<smiles>Cc1c(C)c2c(c(C)c1OC(C)C)CCC(C)(CCCC(C)CCCC(C)CCCC(C)C)O2</smiles>

A4<smiles>CC(C)OCCC[C@H](NC(=O)c1ccc(NCC2=NC3C(=O)N=C(N)NC3N=C2)cc1)C(=O)O</smiles>

Figure 16. Structures of the $3 \mathrm{D}-\mathrm{QSAR}$ designed compounds.

were in the range of 3.92-8.96 (Table 21). The obtained values revealed that the compounds here have complex synthesis route.

Absorption, distribution, metabolism and excretion properties evaluation of the top hit compounds. Solubility is one of the major properties influencing absorption. The compound's aqueous and non-aqueous solubility either is important from the drug development process until oral in-take ${ }^{67}$. Lipophilicity is the effective solubility of a compound into the non-aqueous medium and correlated to various models of drug properties such as adsorption, distribution, metabolism and toxicity ${ }^{70}$. Five available predictive models, i.e iLOGP (implicit $\log \mathrm{P}_{o / w}$ ), XLOGP3 (enhanced atomic/hybrid $\log \mathrm{P}_{o / w}$ ), WLOGP (Wildman and Crippen log $\mathrm{P}_{o / w}$ ), MLOGP (quantitative-structure $\log \mathrm{P}_{o / w}$ ) and SILICOS-IT were used to evaluate the lipophilicity of the compounds. The mean predicted lipophilicity values from these methods is termed as the consensus $\log \mathrm{P}_{o / w}$. A molecule is more soluble if the consensus $\log \mathrm{P}_{o / w}$ values is more negative ${ }^{67}$. Results showed that compounds \#4, \#27, and \#65 were soluble in non-aqueous medium (Table 22). 


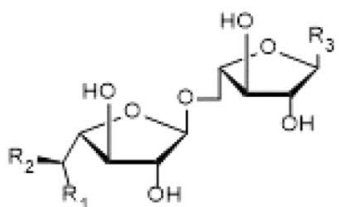

$\begin{array}{lll}\mathbf{R}_{1}=\mathrm{CH}_{3} & \mathrm{R}_{1}=\mathrm{CH}_{3} & \mathrm{R}_{1}=\mathrm{CH}_{3} \\ \mathbf{R}_{2}=\mathrm{OH} & \mathrm{R}_{2}=\mathrm{OH} & \mathrm{R}_{2}=\mathrm{OH} \\ \mathbf{R}_{3}=\mathrm{A} 2 & \mathrm{R}_{3}=\mathrm{A} 2 & \mathbf{R}_{3}=\mathrm{A} 2\end{array}$

66
68<smiles>C=C1CC[C@@H](OC(C)C)C/C1=C/C=C1\CCCC2(C)C([C@@H](C)CCCC(C)C)CC[C@@H]12</smiles>

A1<smiles>C=c1ccc(OC(C)C)cc1=CC=C1C=CCC2(C)C1CCC2[C@@H](C)CCCC(C)C</smiles>

A3<smiles>C=c1ccc(OC(C)C)c/c1=C/C=c1\cccc2c1=C[N+](C)=C2[C@H](C)CCCC(C)C</smiles>

A5<smiles>[R3]C1OC(O)C2C([R3])OC1C2O</smiles>

$$
\begin{array}{llll}
\mathbf{R}_{1}=\mathrm{CH}_{3} & \mathrm{R}_{1}=\mathrm{CH}_{3} & \mathrm{R}_{1}=\mathrm{CH}_{3} & \mathbf{R}_{1}=\mathrm{CH}_{3} \\
\mathbf{R}_{2}=\mathrm{NH}_{3} & \mathrm{R}_{2}=\mathrm{NH}_{3} & \mathbf{R}_{2}=\mathrm{NH}_{3} & \mathbf{R}_{2}=\mathrm{NH}_{3} \\
\mathbf{R}_{3}=\mathrm{A} 1 & \mathbf{R}_{3}=\mathrm{A} 3 & \mathbf{R}_{3}=\mathrm{A}_{4} & \mathbf{R}_{3}=\mathrm{A} 5
\end{array}
$$

69

70

71

72

$$
\begin{array}{clc}
\mathrm{R}_{1}=\mathrm{CH}_{3} & \mathrm{R}_{1}=\mathrm{CH}_{3} & \mathrm{R}_{1}=\mathrm{CH}_{3} \\
\mathrm{R}_{2}=\mathrm{NH}_{3} & \mathrm{R}_{2}=\mathrm{NH}_{3} & \mathrm{R}_{2}=\mathrm{NH}_{3} \\
\mathrm{R}_{3}=\mathrm{A} 4 & \mathrm{R}_{3}=\mathrm{A} \mathrm{G} & \mathrm{R}_{3}=\mathrm{A} 7 \\
73 & 74 & 75
\end{array}
$$<smiles>C=C1CC[C@@H](OC(C)C)C/C1=C/C=C1\CCCC2(C)C1CCC2[C@H](C)CCCC(C)C</smiles>

A2<smiles>C=c1ccc(OC(C)C)c/c1=C/C=c1\cccc2c1=CN=C2[C@H](C)CCCC(C)C</smiles>

A4<smiles>C=c1ccc(OC(C)C)c/c1=C/C=C1\C=CCC2(C)[C@@H]1CC[C@H]2[C@H](C)CCCc1nnn[nH]1</smiles>

A6<smiles>C=c1ccc(OC(C)(C)C)c/c1=C/C=C1\C=CC[C@@]2(C)C1CCC2[C@H](C)Cc1nnn[nH]1</smiles>

Figure 17. 3D-QSAR Designed Possible Inhibitors.

Some drugs have to be highly water soluble to deliver sufficient amount of the active ingredient. Three models were used by SwissADME to predict water solubility i.e ESOL (Estimated SOLubility), Ali and SILICOS-IT (SwissADME in-house solubility predictor). A qualitative estimation of solubility according to log S scale: $<-10$ - poorly soluble, $<-6$ - moderately soluble, $<-4$ - soluble, $<-2$ - very soluble, and $<0$ highly soluble ${ }^{67}$. Based from these predictive models, only compound 65 is predicted to be soluble. Compounds \#1, \#3, and \#4 are predicted to be water soluble while compounds \#27, \#61, \#63, \#73 and \#75 are predicted to be moderately water soluble. The remaining top hit compounds are predicted to be water insoluble (Table 22).

As the drug is absorbed by the system, it encounters diverse membrane barriers such as hepatocyte membrane, gastrointestinal epithelial cells, blood capillary wall, glomerulus, restrictive organ barriers (e.g. blood-brain-barrier), and the target cell ${ }^{70}$. A molecule is said to be less skin permeant if the value of $\log \mathrm{K}_{p}$ is more negative ${ }^{67,72}$. From the predicted results, compounds \#4, \#27 and \#65 are found to be the least skin permeant (Table 23). Moreover, other parameters used to measure the adsorption and distribution of these drugs is through human intestinal absorption (HIA) or gastrointestinal (GI) adsorption data. These data show that compounds \#31, \#70,\#71,\#72, and \#73 are predicted to be well-absorbed, whereas, compounds \#31, \#70, \#71, 


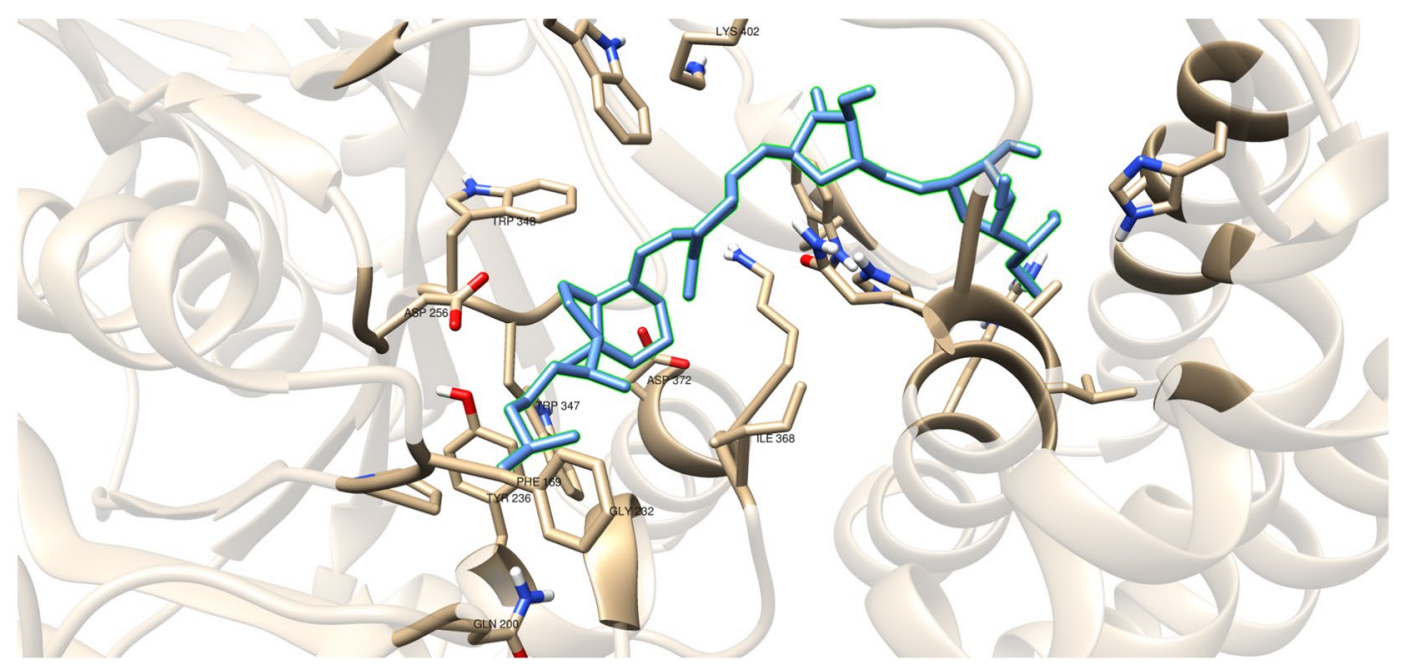

Figure 18. Three-dimensional plot of the interaction of compound \#60 with GlfT2's active site.

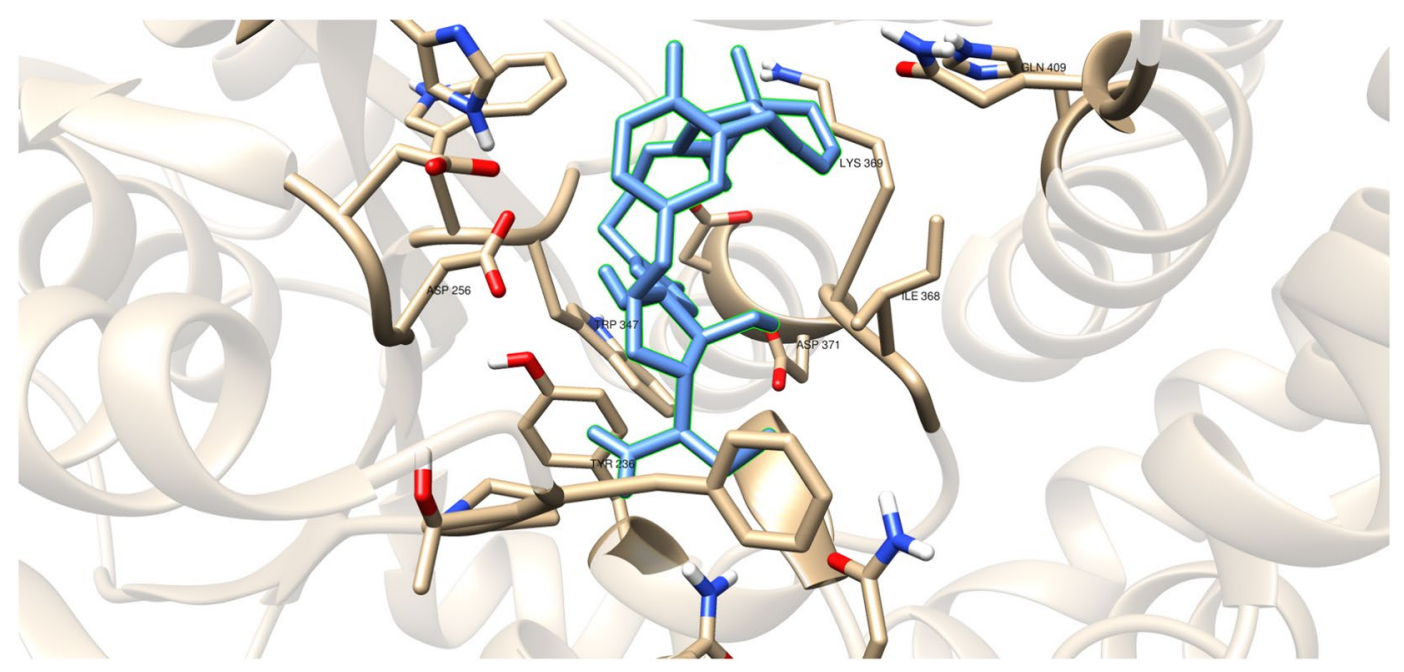

Figure 19. Three-dimensional plot of the interaction of compound \#74 with GlfT2's active site.

$\# 72$, and \#73 are predicted as non-brain penetrants (Table 23). None of the top hit compounds was predicted to be blood-brain-barrier (BBB) permeant. This means that compounds being proposed here have a relatively large size and they cannot pass the blood-brain barrier. Also, a compound being non-blood-brain permeant lowers the possibility of causing harmful toxicants in the brain and blood stream when metabolized. The remaining compounds were predicted to be neither absorbed nor penetrated in the brain.

After being distributed to the organism's system, metabolism of these drugs takes place and eventually exit the excreta safely. Metabolism plays an important role in the bioavailability of drugs as well as drug-drug interactions. It is also important to have a better understanding if a certain compound is a substrate or non-substrate of the permeability glycoprotein (P-gp). This protein belongs to the ATP-binding cassette transporters which is important in assessing active efflux through biological membranes. It is also essential to have knowledge of the interaction of molecules with cytochrome P450 (CYP) enzymes as they are involved in drug elimination through metabolic transformation ${ }^{73}$. It has been suggested that CYP and P-gp can process small molecules synergistically to enhance the protection of tissues and organisms ${ }^{74}$. Inhibition of these isoenzymes may result in pharmacokinetics-related drug-drug interactions that could lead to unwanted adverse side-effects by lowering the solubility and the accumulation of the drug or its metabolites. To better understand the mechanism of drug deposition, efficacy and toxicity, the top hit compounds were evaluated to determine whether the compound can act as substrate or an inhibitor of P-gp and CYPs. All compounds are found to be substrates of P-gp except for compounds \#1, \#2, \#4, \#61 and \#69. Moreover, the top hit compounds presented were found to be substrates of CYP1A2, CYP2C19 and CYP2D6. All compounds are predicted to be CYP2C9 substrates except compounds \#31 


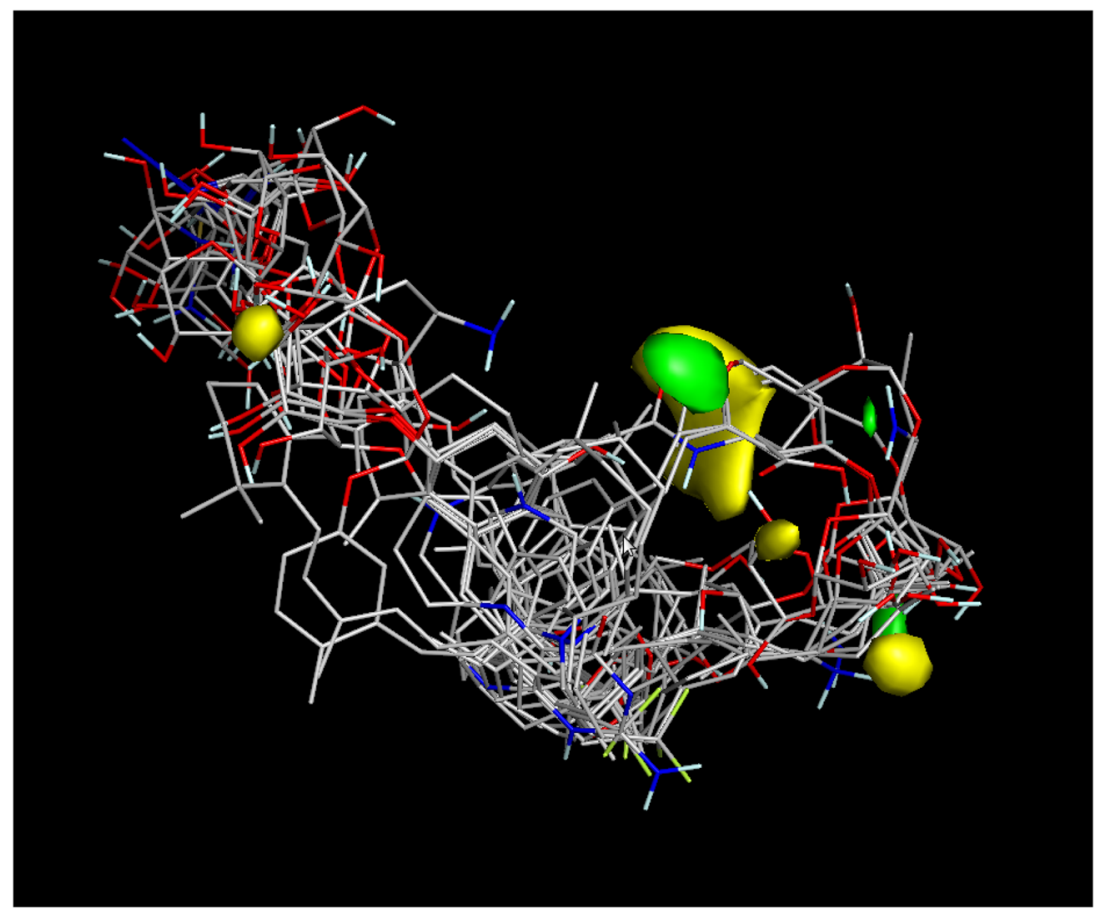

Figure 20. 3D-QSAR model for the synthesized GlfT2 compounds $\left(\mathrm{R}^{2}=0.99\right)$. Yellow isosurface represents the positive steric field, green isosurface represents the negative steric field.

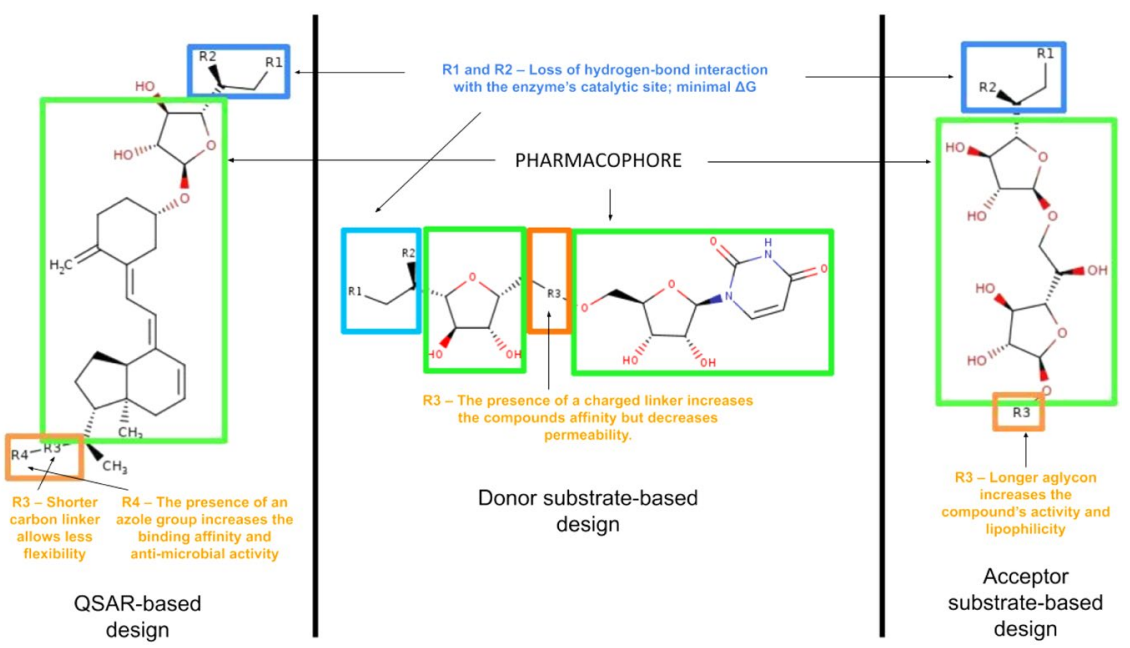

Figure 21. Structure-Activity Relationship (SAR) representation of the QSAR-based design, donor substratebased design and acceptor substrate-based design compounds.

and \#73, whereas, for CYP3A4, compounds \#27, \#58, \#59, \#63, \#64, \#65, \#68, and \#72 were found to be potential substrates (Table 24).

In silico toxicity evaluation of top hit compounds. Investigating the ADMET properties of a compound is a critical step for drug development. If a drug passes this step, subsequent toxicity tests are warranted. However, toxicity tests are time consuming and expensive especially if there are significant number of candidate compounds ${ }^{75,76}$. To keep up with increasing demand from the pharmaceutical industries, in silico toxicity evaluation is initially used to determine the compound's toxicity as a fast and an inexpensive method to reduce the number of compounds to be sent later for further testing. In silico toxicity evaluation could not act as absolute answer for the compound's toxicity evaluation $^{75}$. Thus, it should always be accompanied by an in vitro and in vivo experiments to verify the biological activities beyond the capability of these computational approaches.

Here, the top hit compounds were subjected to an in silico toxicity evaluation using Pro-Tox. The $\mathrm{LD}_{50}$ is defined as the median lethal dose of a compound at which the test subjects die upon exposure to it. The toxicity 


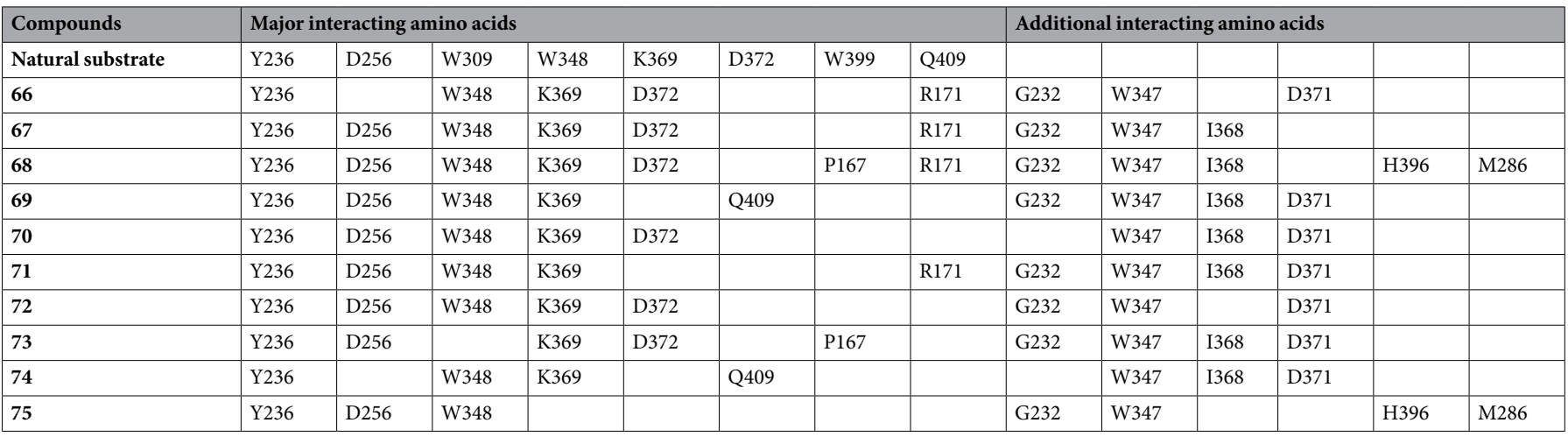

Table 20. Interacting amino acids with $3 \mathrm{D}-\mathrm{QSAR}$ designed compounds.

\begin{tabular}{|c|c|c|c|c|c|c|c|}
\hline \multirow[b]{2}{*}{ Compound } & \multicolumn{6}{|c|}{ Drug-likeness } & \multirow[b]{2}{*}{$\begin{array}{l}\text { Synthetic } \\
\text { Accessibility }\end{array}$} \\
\hline & \begin{tabular}{|l|} 
MW \\
$(\mathrm{g} / \mathrm{mol})$
\end{tabular} & \begin{tabular}{|l|} 
TPSA \\
$\left(\AA^{2}\right)$
\end{tabular} & $\begin{array}{l}\text { ESOL } \\
\log S\end{array}$ & \begin{tabular}{|l} 
Fraction \\
Csp3
\end{tabular} & $\begin{array}{l}\text { \#Rotatable } \\
\text { bonds }\end{array}$ & $\begin{array}{l}\text { Bioavailability } \\
\text { Score }\end{array}$ & \\
\hline 1 & 551.63 & 228.28 & -3.55 & 1 & 19 & 0.11 & 6.9 \\
\hline 2 & 517.61 & 187.82 & -4.57 & 0.92 & 18 & 0.11 & 6.68 \\
\hline 3 & 584.72 & 248.67 & -2.71 & 0.96 & 20 & 0.17 & 6.81 \\
\hline 4 & 452.42 & 269.95 & 0.89 & 0.93 & 12 & 0.11 & 5.8 \\
\hline 27 & 635.52 & 312.43 & -3.24 & 0.22 & 11 & 0.17 & 5.3 \\
\hline 31 & 550.26 & 97.93 & -7.23 & 0.16 & 5 & 0.56 & 3.92 \\
\hline 58 & 733.96 & 215.95 & -7.45 & 0.92 & 14 & 0.11 & 8.69 \\
\hline 59 & 731.94 & 215.95 & -6.99 & 0.82 & 15 & 0.11 & 8.55 \\
\hline 60 & 676.92 & 138.07 & -7.22 & 0.85 & 13 & 0.55 & 8.61 \\
\hline 61 & 578.73 & 138.07 & -5.28 & 0.69 & 12 & 0.55 & 7.51 \\
\hline 62 & 688.89 & 147.3 & -7.44 & 0.69 & 16 & 0.55 & 7.62 \\
\hline 63 & 708.92 & 178.53 & -5.6 & 0.85 & 13 & 0.17 & 8.72 \\
\hline 64 & 737 & 208.21 & -6.47 & 0.82 & 15 & 0.17 & 8.42 \\
\hline 65 & 719.7 & 314.05 & -1.87 & 0.55 & 17 & 0.11 & 6.48 \\
\hline 66 & 730.89 & 138.07 & -7.73 & 0.85 & 14 & 0.55 & 8.53 \\
\hline 67 & \begin{tabular}{|l|l|}
772.97 \\
\end{tabular} & \begin{tabular}{|l}
138.07 \\
\end{tabular} & -8.63 & 0.86 & 15 & 0.55 & 8.96 \\
\hline 68 & 731.88 & \begin{tabular}{|l|}
150.1 \\
\end{tabular} & -7.1 & 0.84 & 14 & 0.17 & \begin{tabular}{|l|}
8.38 \\
\end{tabular} \\
\hline 69 & 543.82 & 84.94 & -7.39 & 0.82 & 10 & 0.17 & 7.53 \\
\hline 70 & 537.77 & 84.94 & -7.54 & 0.65 & 10 & \begin{tabular}{|l|}
0.17 \\
\end{tabular} & 7.07 \\
\hline 71 & 518.69 & 97.3 & -5.91 & 0.47 & 10 & 0.55 & \begin{tabular}{|l|l|}
6.54 \\
\end{tabular} \\
\hline 72 & 533.72 & 89.87 & -6.84 & \begin{tabular}{|l|}
0.48 \\
\end{tabular} & 10 & 0.55 & 6.25 \\
\hline 73 & 506.68 & 97.3 & -5.65 & 0.52 & 10 & 0.55 & 6.74 \\
\hline 74 & 563.73 & \begin{tabular}{|l|}
139.4 \\
\end{tabular} & -6.24 & 0.59 & 10 & 0.55 & 6.93 \\
\hline 75 & 539.71 & \begin{tabular}{|l|}
139.4 \\
\end{tabular} & -5.3 & \begin{tabular}{|l|} 
\\
\end{tabular} & 8 & 0.55 & 7.07 \\
\hline
\end{tabular}

Table 21. Drug-likeness parameter values for the top hit compounds.

class ranges from 1 to 6,1 being fatal if ingested and 6 being non-toxic ${ }^{77}$. The results showed that the top hit compounds \#3, \#4, \#63, \#65, \#66, \#67, and \#73 were predicted to be orally toxic (range between toxicity class 1 to 3 ) (Table 25).

The Pro-Tox online server ${ }^{68}$ also predicts four toxicological endpoints such as cytotoxicity, mutagenicity, carcinogenicity, and immunotoxicity. Results suggested that all the top hit compounds were predicted to be immunotoxic except for compound \#31 (Table 26). Immunotoxic chemicals are known to alter the correct functioning of immune system by B cell growth inhibition ${ }^{68,77}$. Moreover, the organ toxicity, specifically hepatotoxicity was predicted to evaluate if the compound will cause liver dysfunction ${ }^{68,77}$. Results showed that the top hit compounds were predicted to be non-hepatotoxic. Moreover, compound \#4 was predicted to be a mutagenic compound (Table 26). This means that it can possibly cause alteration of a genetic material, such as the DNA of an organism.

Lastly, toxicity of the compounds depends on the different metabolic mechanisms. Several enzymes could either metabolize the drug therapeutically or lead to the formation of toxic metabolites. Below are the possible targets defined according to Novartis that are linked with adverse drug reactions: Adenosine A2A receptor (AA2AR), Adrenergic beta 


\begin{tabular}{|c|c|c|c|}
\hline Compound & Consensus $\log P_{o / w}$ & Consensus $\log \mathrm{S}$ & Solubility class \\
\hline 1 & 0.89 & -3.64 & soluble \\
\hline 2 & 1.99 & -4.73 & moderately soluble \\
\hline 3 & 0.41 & -2.85 & soluble \\
\hline 4 & -3.64 & 0.97 & very soluble \\
\hline 27 & -1.37 & -4.29 & moderately soluble \\
\hline 31 & 5.41 & -7.49 & poorly soluble \\
\hline 58 & 3.63 & -7.14 & poorly soluble \\
\hline 59 & 3.62 & -6.86 & poorly soluble \\
\hline 60 & 5.08 & -6.75 & poorly soluble \\
\hline 61 & 3.51 & -4.58 & moderately soluble \\
\hline 62 & 5.44 & -7.47 & poorly soluble \\
\hline 63 & 3.33 & -5.03 & moderately soluble \\
\hline 64 & 3.92 & -6.25 & poorly soluble \\
\hline 65 & -1.63 & -2.82 & soluble \\
\hline 66 & 5.57 & -7.2 & poorly soluble \\
\hline 67 & 6.26 & -8.06 & poorly soluble \\
\hline 68 & 4.74 & -6.64 & poorly soluble \\
\hline 69 & 6.2 & -7.37 & poorly soluble \\
\hline 70 & 5.91 & -7.67 & poorly soluble \\
\hline 71 & 4.3 & -6.65 & poorly soluble \\
\hline 72 & 3.63 & -6.78 & poorly soluble \\
\hline 73 & 4.22 & -5.87 & moderately soluble \\
\hline 74 & 4.06 & -6.7 & poorly soluble \\
\hline 75 & 3.58 & -5.3 & moderately soluble \\
\hline
\end{tabular}

Table 22. Predicted absorption parameters in ADME evaluation of top hit compounds.

\begin{tabular}{|c|c|c|c|}
\hline Compound & GI absorption & BBB permeant & $\log K_{p}(\mathrm{~cm} / \mathrm{s})$ \\
\hline 1 & Low & No & -7.93 \\
\hline 2 & Low & No & -6.4 \\
\hline 3 & Low & No & -9.23 \\
\hline 4 & Low & No & -12.16 \\
\hline 27 & Low & No & -10.31 \\
\hline 31 & High & No & -5.17 \\
\hline 58 & Low & No & -6.29 \\
\hline 59 & Low & No & -6.7 \\
\hline 60 & Low & No & -5.88 \\
\hline 61 & Low & No & -6.85 \\
\hline 62 & Low & No & -5.66 \\
\hline 63 & Low & No & -8.12 \\
\hline 64 & Low & No & -7.35 \\
\hline 65 & Low & No & -12.43 \\
\hline 66 & Low & No & -5.93 \\
\hline 67 & Low & No & -5.39 \\
\hline 68 & Low & No & -6.66 \\
\hline 69 & Low & No & -4.16 \\
\hline 70 & High & No & -4.05 \\
\hline 71 & High & No & -5.76 \\
\hline 72 & High & No & -4.97 \\
\hline 73 & High & No & -5.77 \\
\hline 74 & Low & No & -5.94 \\
\hline 75 & Low & No & -6.72 \\
\hline
\end{tabular}

Table 23. Predicted distribution parameters in ADME evaluation of top hit compounds. 


\begin{tabular}{|c|c|c|c|c|c|c|}
\hline Compound & \begin{tabular}{|l|} 
P-gp \\
substrate
\end{tabular} & $\begin{array}{l}\text { CYP1A2 } \\
\text { inhibitor }\end{array}$ & $\begin{array}{l}\text { CYP2C19 } \\
\text { inhibitor }\end{array}$ & \begin{tabular}{|l|} 
CYP2C9 \\
inhibitor
\end{tabular} & $\begin{array}{l}\text { CYP2D6 } \\
\text { inhibitor }\end{array}$ & \begin{tabular}{|l|} 
CYP3A4 \\
inhibitor
\end{tabular} \\
\hline 1 & Yes & No & No & No & No & No \\
\hline 2 & Yes & No & No & No & No & No \\
\hline 3 & No & No & No & No & No & No \\
\hline 4 & Yes & No & No & No & No & No \\
\hline 27 & Yes & No & No & No & No & No \\
\hline 31 & No & No & No & Yes & No & Yes \\
\hline 58 & Yes & No & No & No & No & No \\
\hline 59 & Yes & No & No & No & No & No \\
\hline 60 & Yes & No & No & No & No & Yes \\
\hline 61 & No & No & No & No & No & Yes \\
\hline 62 & Yes & No & No & No & No & Yes \\
\hline 63 & Yes & No & No & No & No & No \\
\hline 64 & Yes & No & No & No & No & No \\
\hline 65 & Yes & No & No & No & No & No \\
\hline 66 & Yes & No & No & No & No & Yes \\
\hline 67 & Yes & No & No & No & No & Yes \\
\hline 68 & Yes & No & No & No & No & No \\
\hline 69 & No & No & No & No & No & Yes \\
\hline 70 & Yes & No & No & No & No & Yes \\
\hline 71 & Yes & No & No & No & No & Yes \\
\hline 72 & Yes & No & No & No & No & No \\
\hline 73 & Yes & No & No & Yes & No & Yes \\
\hline 74 & Yes & No & No & No & No & Yes \\
\hline 75 & Yes & No & No & No & No & Yes \\
\hline
\end{tabular}

Table 24. Predicted metabolism parameters in ADME evaluation of top hit compounds.

\begin{tabular}{|c|c|c|}
\hline Compound & Predicted $\mathrm{LD}_{50}(\mathrm{mg} / \mathrm{kg})$ & Toxicity class \\
\hline 1 & 2275 & 4 \\
\hline 2 & 2275 & 4 \\
\hline 3 & 50 & 2 \\
\hline 4 & 250 & 3 \\
\hline 27 & 1000 & 4 \\
\hline 31 & 350 & 4 \\
\hline 58 & 590 & 4 \\
\hline 59 & 250 & 3 \\
\hline 60 & 55 & 4 \\
\hline 61 & 4000 & 5 \\
\hline 62 & 3000 & 5 \\
\hline 63 & 55 & 3 \\
\hline 64 & 5000 & 5 \\
\hline 65 & 135 & 3 \\
\hline 66 & 55 & 3 \\
\hline 67 & 55 & 3 \\
\hline 68 & 590 & 4 \\
\hline 69 & 5000 & 5 \\
\hline 70 & 2500 & 5 \\
\hline 71 & 2500 & 5 \\
\hline 72 & 2500 & 5 \\
\hline 73 & 40 & 2 \\
\hline 74 & 2500 & 5 \\
\hline 75 & 590 & 4 \\
\hline
\end{tabular}

Table 25. Predicted $\mathrm{LD}_{50}$ and Toxicity class of the top hit compounds. 


\begin{tabular}{|c|c|c|c|c|c|}
\hline Compound & Hepatotoxicity & Carcinogenicity & Immunotoxicity & Mutagenicity & Cytotoxicity \\
\hline 1 & Inactive & Inactive & Active & Inactive & Inactive \\
\hline 2 & Inactive & Inactive & Active & Inactive & Inactive \\
\hline 3 & Inactive & Inactive & Active & Inactive & Inactive \\
\hline 4 & Inactive & Inactive & Active & Active & Inactive \\
\hline 27 & Inactive & Inactive & Active & Inactive & Inactive \\
\hline 31 & Inactive & Inactive & Inactive & Inactive & Inactive \\
\hline 58 & Inactive & Inactive & Active & Inactive & Inactive \\
\hline 59 & Inactive & Inactive & Active & Inactive & Inactive \\
\hline 60 & Inactive & Inactive & Active & Inactive & Inactive \\
\hline 61 & Inactive & Inactive & Active & Inactive & Inactive \\
\hline 62 & Inactive & Inactive & Active & Inactive & Inactive \\
\hline 63 & Inactive & Inactive & Active & Inactive & Inactive \\
\hline 64 & Inactive & Inactive & Active & Inactive & Inactive \\
\hline 65 & Inactive & Inactive & Active & Inactive & Inactive \\
\hline 66 & Inactive & Inactive & Active & Inactive & Inactive \\
\hline 67 & Inactive & Inactive & Active & Inactive & Inactive \\
\hline 68 & Inactive & Inactive & Active & Inactive & Inactive \\
\hline 69 & Inactive & Inactive & Active & Inactive & Inactive \\
\hline 70 & Inactive & Inactive & Active & Inactive & Inactive \\
\hline 71 & Inactive & Inactive & Active & Inactive & Inactive \\
\hline 72 & Inactive & Inactive & Active & Inactive & Inactive \\
\hline 73 & Inactive & Inactive & Active & Inactive & Inactive \\
\hline 74 & Inactive & Inactive & Active & Inactive & Inactive \\
\hline 75 & Inactive & Inactive & Active & Inactive & Inactive \\
\hline
\end{tabular}

Table 26. Predicted activity of the top hit compounds on toxicity endpoints.

2 receptor (ADRB2), Androgen receptor (ANDR), Amine oxidase (AOFA), Dopamine D3 receptor (DRD3), Estrogen receptor 1 (ESR1) and 2 (ESR2), Glucocorticoid receptor (GCR), Histamine H1 receptor (HRH1), Nuclear receptor subfamily 1 group I member 2 (NR1I2), Opioid receptor $\kappa$ (OPRK), Opioid receptor $\mu$ (OPRM), cAMP-specific $3^{\prime}$, $5^{\prime}$-cyclic phosphodiesterase 4D (PDE4D), Prostaglandin G/H synthase 1 (PGH1), and Progesterone receptor (PRGR) ${ }^{78}$. The results showed that the top hit compounds are non-binders with these protein except for compounds \#4 and\# 65 which were predicted as binders of Prostaglandin G/H synthase 1 (Table 27).

\section{Conclusion}

Tuberculosis is still a worldwide health problem due to the emergence of strains of $M$. tuberculosis that are resistant to existing anti-TB drugs. There is now a growing interest in targeting GlfT2, the enzyme responsible for the growth of the galactan chain, an important part of the cell wall. To obtain insights on the different interactions of the synthesized compounds with GlfT2, we did ensemble molecular docking studies and the binding energy values of the synthesized compounds showed a $-3.00 \mathrm{kcal}$ to $-6.00 \mathrm{kcal} \mathrm{mol}^{-1}$ range. Two compounds, \#27 and $\# 31$, have registered binding energy value of $-8.32 \pm 0.01$ and $-8.08 \pm 0.01 \mathrm{kcal} \mathrm{mol}^{-1}$, respectively. These compounds are synthesized as UGM inhibitors and could possibly inhibit GlfT2. Compounds \#1-4 are analogs of a known substrate disaccharide modified at 6-OH and 5-OH position of the non-reducing end. Docking studies showed that these are promising compounds with binding energy values of -10.00 to $-19.00 \mathrm{kcal} \mathrm{mol}^{-1}$. The synthesized and designed compounds were subjected to 3D-QSAR to improve their structural scaffolds and effective interactions with the GlfT2 active site. Here, 18 newly designed compounds were produced considering all steric and electrostatic descriptors. Furthermore, these 18 compounds were all subjected to molecular docking and showed increased binding energy values from -6.00 to $-8.00 \mathrm{kcal} \mathrm{mol}^{-1}$. Also, a significant increase on the binding energy value was observed when modifying the aglycon part instead of the sugar moiety. Thus, it is suggested that a modification of the aglycon could a better putative way to design GlfT2 inhibitors.

The drug development process includes ADMETox evaluation to determine if a certain proposed drug can be absorbed or can be toxic, thus, top hit compounds were subjected to in silico ADMETox. Compounds \#31 and $\# 70-73$ are predicted to be well-absorbed and non-blood brain permeant. Moreover, compounds \#31 and \#73 were considered CYP2C9 inhibitor which could lead to adverse side effects. Compounds \#70, \#71, and \#72 passed the ADME evaluation. Predicted toxicity evaluation showed that only compound \#31 was non-toxic and passed all the toxicity endpoints.

\section{Methods}

Molecular dynamics simulation. Two GlfT2 crystal structures are available in PDB. One is bound with UDP-Galf (PDB ID: 4FIY) and the other one is unbound (PDB ID: 4FIX) ${ }^{20}$. The binding affinity of the natural acceptor substrate, with or without the presence of donor substrate in the active site, is statistically insignificant. Thus, for system simplification, the unbound GlfT2 crystal structure (PDB ID: 4FIX) was used for $100 \mathrm{~ns}$ all-atom 


\begin{tabular}{|c|c|c|c|c|c|c|c|c|c|c|c|c|c|c|c|}
\hline Compound & AA2AR & ADRB2 & ANDR & AOFA & DRD3 & ESR1 & ESR2 & GCR & HRH1 & NR1I2 & OPRK & OPRM & PDE4D & PGH1 & PRGR \\
\hline 1 & $\begin{array}{l}\text { Non- } \\
\text { binder }\end{array}$ & $\begin{array}{l}\text { Non- } \\
\text { binder }\end{array}$ & $\begin{array}{l}\text { Non- } \\
\text { binder }\end{array}$ & $\begin{array}{l}\text { Non- } \\
\text { binder }\end{array}$ & $\begin{array}{l}\text { Non- } \\
\text { binder }\end{array}$ & $\begin{array}{l}\text { Non- } \\
\text { binder }\end{array}$ & $\begin{array}{l}\text { Non- } \\
\text { binder }\end{array}$ & $\begin{array}{l}\text { Non- } \\
\text { binder }\end{array}$ & $\begin{array}{l}\text { Non- } \\
\text { binder }\end{array}$ & $\begin{array}{l}\text { Non- } \\
\text { binder }\end{array}$ & $\begin{array}{l}\text { Non- } \\
\text { binder }\end{array}$ & $\begin{array}{l}\text { Non- } \\
\text { binder }\end{array}$ & $\begin{array}{l}\text { Non- } \\
\text { binder }\end{array}$ & $\begin{array}{l}\text { Non- } \\
\text { binder }\end{array}$ & $\begin{array}{l}\text { Non- } \\
\text { binder }\end{array}$ \\
\hline 2 & $\begin{array}{l}\text { Non- } \\
\text { binder }\end{array}$ & $\begin{array}{l}\text { Non- } \\
\text { binder }\end{array}$ & $\begin{array}{l}\text { Non- } \\
\text { binder }\end{array}$ & $\begin{array}{l}\text { Non- } \\
\text { binder }\end{array}$ & $\begin{array}{l}\text { Non- } \\
\text { binder }\end{array}$ & $\begin{array}{l}\text { Non- } \\
\text { binder }\end{array}$ & $\begin{array}{l}\text { Non- } \\
\text { binder }\end{array}$ & $\begin{array}{l}\text { Non- } \\
\text { binder }\end{array}$ & $\begin{array}{l}\text { Non- } \\
\text { binder }\end{array}$ & $\begin{array}{l}\text { Non- } \\
\text { binder }\end{array}$ & $\begin{array}{l}\text { Non- } \\
\text { binder }\end{array}$ & $\begin{array}{l}\text { Non- } \\
\text { binder }\end{array}$ & $\begin{array}{l}\text { Non- } \\
\text { binder }\end{array}$ & $\begin{array}{l}\text { Non- } \\
\text { binder }\end{array}$ & $\begin{array}{l}\text { Non- } \\
\text { binder }\end{array}$ \\
\hline 3 & $\begin{array}{l}\text { Non- } \\
\text { binder }\end{array}$ & $\begin{array}{l}\text { Non- } \\
\text { binder }\end{array}$ & $\begin{array}{l}\text { Non- } \\
\text { binder }\end{array}$ & $\begin{array}{l}\text { Non- } \\
\text { binder }\end{array}$ & $\begin{array}{l}\text { Non- } \\
\text { binder }\end{array}$ & $\begin{array}{l}\text { Non- } \\
\text { binder }\end{array}$ & $\begin{array}{l}\text { Non- } \\
\text { binder }\end{array}$ & $\begin{array}{l}\text { Non- } \\
\text { binder }\end{array}$ & $\begin{array}{l}\text { Non- } \\
\text { binder }\end{array}$ & $\begin{array}{l}\text { Non- } \\
\text { binder }\end{array}$ & $\begin{array}{l}\text { Non- } \\
\text { binder }\end{array}$ & $\begin{array}{l}\text { Non- } \\
\text { binder }\end{array}$ & $\begin{array}{l}\text { Non- } \\
\text { binder }\end{array}$ & $\begin{array}{l}\text { Non- } \\
\text { binder }\end{array}$ & $\begin{array}{l}\text { Non- } \\
\text { binder }\end{array}$ \\
\hline 4 & $\begin{array}{l}\text { Non- } \\
\text { binder }\end{array}$ & $\begin{array}{l}\text { Non- } \\
\text { binder }\end{array}$ & $\begin{array}{l}\text { Non- } \\
\text { binder }\end{array}$ & $\begin{array}{l}\text { Non- } \\
\text { binder }\end{array}$ & $\begin{array}{l}\text { Non- } \\
\text { binder }\end{array}$ & $\begin{array}{l}\text { Non- } \\
\text { binder }\end{array}$ & $\begin{array}{l}\text { Non- } \\
\text { binder }\end{array}$ & $\begin{array}{l}\text { Non- } \\
\text { binder }\end{array}$ & $\begin{array}{l}\text { Non- } \\
\text { binder }\end{array}$ & $\begin{array}{l}\text { Non- } \\
\text { binder }\end{array}$ & $\begin{array}{l}\text { Non- } \\
\text { binder }\end{array}$ & $\begin{array}{l}\text { Non- } \\
\text { binder }\end{array}$ & $\begin{array}{l}\text { Non- } \\
\text { binder }\end{array}$ & $\begin{array}{l}\text { Non- } \\
\text { binder }\end{array}$ & Binder \\
\hline 27 & $\begin{array}{l}\text { Non- } \\
\text { binder }\end{array}$ & $\begin{array}{l}\text { Non- } \\
\text { binder }\end{array}$ & $\begin{array}{l}\text { Non- } \\
\text { binder }\end{array}$ & $\begin{array}{l}\text { Non- } \\
\text { binder }\end{array}$ & $\begin{array}{l}\text { Non- } \\
\text { binder }\end{array}$ & $\begin{array}{l}\text { Non- } \\
\text { binder }\end{array}$ & $\begin{array}{l}\text { Non- } \\
\text { binder }\end{array}$ & $\begin{array}{l}\text { Non- } \\
\text { binder }\end{array}$ & $\begin{array}{l}\text { Non- } \\
\text { binder }\end{array}$ & $\begin{array}{l}\text { Non- } \\
\text { binder }\end{array}$ & $\begin{array}{l}\text { Non- } \\
\text { binder }\end{array}$ & $\begin{array}{l}\text { Non- } \\
\text { binder }\end{array}$ & $\begin{array}{l}\text { Non- } \\
\text { binder }\end{array}$ & $\begin{array}{l}\text { Non- } \\
\text { binder }\end{array}$ & $\begin{array}{l}\text { Non- } \\
\text { binder }\end{array}$ \\
\hline 31 & $\begin{array}{l}\text { Non- } \\
\text { binder }\end{array}$ & $\begin{array}{l}\text { Non- } \\
\text { binder }\end{array}$ & $\begin{array}{l}\text { Non- } \\
\text { binder }\end{array}$ & $\begin{array}{l}\text { Non- } \\
\text { binder }\end{array}$ & $\begin{array}{l}\text { Non- } \\
\text { binder }\end{array}$ & $\begin{array}{l}\text { Non- } \\
\text { binder }\end{array}$ & $\begin{array}{l}\text { Non- } \\
\text { binder }\end{array}$ & $\begin{array}{l}\text { Non- } \\
\text { binder }\end{array}$ & $\begin{array}{l}\text { Non- } \\
\text { binder }\end{array}$ & $\begin{array}{l}\text { Non- } \\
\text { binder }\end{array}$ & $\begin{array}{l}\text { Non- } \\
\text { binder }\end{array}$ & $\begin{array}{l}\text { Non- } \\
\text { binder }\end{array}$ & $\begin{array}{l}\text { Non- } \\
\text { binder }\end{array}$ & $\begin{array}{l}\text { Non- } \\
\text { binder }\end{array}$ & $\begin{array}{l}\text { Non- } \\
\text { binder }\end{array}$ \\
\hline 58 & $\begin{array}{l}\text { Non- } \\
\text { binder }\end{array}$ & $\begin{array}{l}\text { Non- } \\
\text { binder }\end{array}$ & $\begin{array}{l}\text { Non- } \\
\text { binder }\end{array}$ & $\begin{array}{l}\text { Non- } \\
\text { binder }\end{array}$ & $\begin{array}{l}\text { Non- } \\
\text { binder }\end{array}$ & $\begin{array}{l}\text { Non- } \\
\text { binder }\end{array}$ & $\begin{array}{l}\text { Non- } \\
\text { binder }\end{array}$ & $\begin{array}{l}\text { Non- } \\
\text { binder }\end{array}$ & $\begin{array}{l}\text { Non- } \\
\text { binder }\end{array}$ & $\begin{array}{l}\text { Non- } \\
\text { binder }\end{array}$ & $\begin{array}{l}\text { Non- } \\
\text { binder }\end{array}$ & $\begin{array}{l}\text { Non- } \\
\text { binder }\end{array}$ & $\begin{array}{l}\text { Non- } \\
\text { binder }\end{array}$ & $\begin{array}{l}\text { Non- } \\
\text { binder }\end{array}$ & $\begin{array}{l}\text { Non- } \\
\text { binder }\end{array}$ \\
\hline 59 & $\begin{array}{l}\text { Non- } \\
\text { binder }\end{array}$ & $\begin{array}{l}\text { Non- } \\
\text { binder }\end{array}$ & $\begin{array}{l}\text { Non- } \\
\text { binder }\end{array}$ & $\begin{array}{l}\text { Non- } \\
\text { binder }\end{array}$ & $\begin{array}{l}\text { Non- } \\
\text { binder }\end{array}$ & $\begin{array}{l}\text { Non- } \\
\text { binder }\end{array}$ & $\begin{array}{l}\text { Non- } \\
\text { binder }\end{array}$ & $\begin{array}{l}\text { Non- } \\
\text { binder }\end{array}$ & $\begin{array}{l}\text { Non- } \\
\text { binder }\end{array}$ & $\begin{array}{l}\text { Non- } \\
\text { binder }\end{array}$ & $\begin{array}{l}\text { Non- } \\
\text { binder }\end{array}$ & $\begin{array}{l}\text { Non- } \\
\text { binder }\end{array}$ & $\begin{array}{l}\text { Non- } \\
\text { binder }\end{array}$ & $\begin{array}{l}\text { Non- } \\
\text { binder }\end{array}$ & $\begin{array}{l}\text { Non- } \\
\text { binder }\end{array}$ \\
\hline 60 & $\begin{array}{l}\text { Non- } \\
\text { binder }\end{array}$ & $\begin{array}{l}\text { Non- } \\
\text { binder }\end{array}$ & $\begin{array}{l}\text { Non- } \\
\text { binder }\end{array}$ & $\begin{array}{l}\text { Non- } \\
\text { binder }\end{array}$ & $\begin{array}{l}\text { Non- } \\
\text { binder }\end{array}$ & $\begin{array}{l}\text { Non- } \\
\text { binder }\end{array}$ & $\begin{array}{l}\text { Non- } \\
\text { binder }\end{array}$ & $\begin{array}{l}\text { Non- } \\
\text { binder }\end{array}$ & $\begin{array}{l}\text { Non- } \\
\text { binder }\end{array}$ & $\begin{array}{l}\text { Non- } \\
\text { binder }\end{array}$ & $\begin{array}{l}\text { Non- } \\
\text { binder }\end{array}$ & $\begin{array}{l}\text { Non- } \\
\text { binder }\end{array}$ & $\begin{array}{l}\text { Non- } \\
\text { binder }\end{array}$ & $\begin{array}{l}\text { Non- } \\
\text { binder }\end{array}$ & $\begin{array}{l}\text { Non- } \\
\text { binder }\end{array}$ \\
\hline 61 & $\begin{array}{l}\text { Non- } \\
\text { binder }\end{array}$ & $\begin{array}{l}\text { Non- } \\
\text { binder }\end{array}$ & $\begin{array}{l}\text { Non- } \\
\text { binder }\end{array}$ & $\begin{array}{l}\text { Non- } \\
\text { binder }\end{array}$ & $\begin{array}{l}\text { Non- } \\
\text { binder }\end{array}$ & $\begin{array}{l}\text { Non- } \\
\text { binder }\end{array}$ & $\begin{array}{l}\text { Non- } \\
\text { binder }\end{array}$ & $\begin{array}{l}\text { Non- } \\
\text { binder }\end{array}$ & $\begin{array}{l}\text { Non- } \\
\text { binder }\end{array}$ & $\begin{array}{l}\text { Non- } \\
\text { binder }\end{array}$ & $\begin{array}{l}\text { Non- } \\
\text { binder }\end{array}$ & $\begin{array}{l}\text { Non- } \\
\text { binder }\end{array}$ & $\begin{array}{l}\text { Non- } \\
\text { binder }\end{array}$ & $\begin{array}{l}\text { Non- } \\
\text { binder }\end{array}$ & $\begin{array}{l}\text { Non- } \\
\text { binder }\end{array}$ \\
\hline 62 & $\begin{array}{l}\text { Non- } \\
\text { binder }\end{array}$ & $\begin{array}{l}\text { Non- } \\
\text { binder }\end{array}$ & $\begin{array}{l}\text { Non- } \\
\text { binder }\end{array}$ & $\begin{array}{l}\text { Non- } \\
\text { binder }\end{array}$ & $\begin{array}{l}\text { Non- } \\
\text { binder }\end{array}$ & $\begin{array}{l}\text { Non- } \\
\text { binder }\end{array}$ & $\begin{array}{l}\text { Non- } \\
\text { binder }\end{array}$ & $\begin{array}{l}\text { Non- } \\
\text { binder }\end{array}$ & $\begin{array}{l}\text { Non- } \\
\text { binder }\end{array}$ & $\begin{array}{l}\text { Non- } \\
\text { binder }\end{array}$ & $\begin{array}{l}\text { Non- } \\
\text { binder }\end{array}$ & $\begin{array}{l}\text { Non- } \\
\text { binder }\end{array}$ & $\begin{array}{l}\text { Non- } \\
\text { binder }\end{array}$ & $\begin{array}{l}\text { Non- } \\
\text { binder }\end{array}$ & $\begin{array}{l}\text { Non- } \\
\text { binder }\end{array}$ \\
\hline 63 & $\begin{array}{l}\text { Non- } \\
\text { binder }\end{array}$ & $\begin{array}{l}\text { Non- } \\
\text { binder }\end{array}$ & $\begin{array}{l}\text { Non- } \\
\text { binder }\end{array}$ & $\begin{array}{l}\text { Non- } \\
\text { binder }\end{array}$ & $\begin{array}{l}\text { Non- } \\
\text { binder }\end{array}$ & $\begin{array}{l}\text { Non- } \\
\text { binder }\end{array}$ & $\begin{array}{l}\text { Non- } \\
\text { binder }\end{array}$ & $\begin{array}{l}\text { Non- } \\
\text { binder }\end{array}$ & $\begin{array}{l}\text { Non- } \\
\text { binder }\end{array}$ & $\begin{array}{l}\text { Non- } \\
\text { binder }\end{array}$ & $\begin{array}{l}\text { Non- } \\
\text { binder }\end{array}$ & $\begin{array}{l}\text { Non- } \\
\text { binder }\end{array}$ & $\begin{array}{l}\text { Non- } \\
\text { binder }\end{array}$ & $\begin{array}{l}\text { Non- } \\
\text { binder }\end{array}$ & $\begin{array}{l}\text { Non- } \\
\text { binder }\end{array}$ \\
\hline 64 & $\begin{array}{l}\text { Non- } \\
\text { binder }\end{array}$ & $\begin{array}{l}\text { Non- } \\
\text { binder }\end{array}$ & $\begin{array}{l}\text { Non- } \\
\text { binder }\end{array}$ & $\begin{array}{l}\text { Non- } \\
\text { binder }\end{array}$ & $\begin{array}{l}\text { Non- } \\
\text { binder }\end{array}$ & $\begin{array}{l}\text { Non- } \\
\text { binder }\end{array}$ & $\begin{array}{l}\text { Non- } \\
\text { binder }\end{array}$ & $\begin{array}{l}\text { Non- } \\
\text { binder }\end{array}$ & $\begin{array}{l}\text { Non- } \\
\text { binder }\end{array}$ & $\begin{array}{l}\text { Non- } \\
\text { binder }\end{array}$ & $\begin{array}{l}\text { Non- } \\
\text { binder }\end{array}$ & $\begin{array}{l}\text { Non- } \\
\text { binder }\end{array}$ & $\begin{array}{l}\text { Non- } \\
\text { binder }\end{array}$ & $\begin{array}{l}\text { Non- } \\
\text { binder }\end{array}$ & $\begin{array}{l}\text { Non- } \\
\text { binder }\end{array}$ \\
\hline 65 & $\begin{array}{l}\text { Non- } \\
\text { binder }\end{array}$ & $\begin{array}{l}\text { Non- } \\
\text { binder }\end{array}$ & $\begin{array}{l}\text { Non- } \\
\text { binder }\end{array}$ & $\begin{array}{l}\text { Non- } \\
\text { binder }\end{array}$ & $\begin{array}{l}\text { Non- } \\
\text { binder }\end{array}$ & $\begin{array}{l}\text { Non- } \\
\text { binder }\end{array}$ & $\begin{array}{l}\text { Non- } \\
\text { binder }\end{array}$ & $\begin{array}{l}\text { Non- } \\
\text { binder }\end{array}$ & $\begin{array}{l}\text { Non- } \\
\text { binder }\end{array}$ & $\begin{array}{l}\text { Non- } \\
\text { binder }\end{array}$ & $\begin{array}{l}\text { Non- } \\
\text { binder }\end{array}$ & $\begin{array}{l}\text { Non- } \\
\text { binder }\end{array}$ & $\begin{array}{l}\text { Non- } \\
\text { binder }\end{array}$ & $\begin{array}{l}\text { Non- } \\
\text { binder }\end{array}$ & Binder \\
\hline 66 & $\begin{array}{l}\text { Non- } \\
\text { binder }\end{array}$ & $\begin{array}{l}\text { Non- } \\
\text { binder }\end{array}$ & $\begin{array}{l}\text { Non- } \\
\text { binder }\end{array}$ & $\begin{array}{l}\text { Non- } \\
\text { binder }\end{array}$ & $\begin{array}{l}\text { Non- } \\
\text { binder }\end{array}$ & $\begin{array}{l}\text { Non- } \\
\text { binder }\end{array}$ & $\begin{array}{l}\text { Non- } \\
\text { binder }\end{array}$ & $\begin{array}{l}\text { Non- } \\
\text { binder }\end{array}$ & $\begin{array}{l}\text { Non- } \\
\text { binder }\end{array}$ & $\begin{array}{l}\text { Non- } \\
\text { binder }\end{array}$ & $\begin{array}{l}\text { Non- } \\
\text { binder }\end{array}$ & $\begin{array}{l}\text { Non- } \\
\text { binder }\end{array}$ & $\begin{array}{l}\text { Non- } \\
\text { binder }\end{array}$ & $\begin{array}{l}\text { Non- } \\
\text { binder }\end{array}$ & $\begin{array}{l}\text { Non- } \\
\text { binder }\end{array}$ \\
\hline 67 & $\begin{array}{l}\text { Non- } \\
\text { binder }\end{array}$ & $\begin{array}{l}\text { Non- } \\
\text { binder }\end{array}$ & $\begin{array}{l}\text { Non- } \\
\text { binder }\end{array}$ & $\begin{array}{l}\text { Non- } \\
\text { binder }\end{array}$ & $\begin{array}{l}\text { Non- } \\
\text { binder }\end{array}$ & $\begin{array}{l}\text { Non- } \\
\text { binder }\end{array}$ & $\begin{array}{l}\text { Non- } \\
\text { binder }\end{array}$ & $\begin{array}{l}\text { Non- } \\
\text { binder }\end{array}$ & $\begin{array}{l}\text { Non- } \\
\text { binder }\end{array}$ & $\begin{array}{l}\text { Non- } \\
\text { binder }\end{array}$ & $\begin{array}{l}\text { Non- } \\
\text { binder }\end{array}$ & $\begin{array}{l}\text { Non- } \\
\text { binder }\end{array}$ & $\begin{array}{l}\text { Non- } \\
\text { binder }\end{array}$ & $\begin{array}{l}\text { Non- } \\
\text { binder }\end{array}$ & $\begin{array}{l}\text { Non- } \\
\text { binder }\end{array}$ \\
\hline 68 & $\begin{array}{l}\text { Non- } \\
\text { binder }\end{array}$ & $\begin{array}{l}\text { Non- } \\
\text { binder }\end{array}$ & $\begin{array}{l}\text { Non- } \\
\text { binder }\end{array}$ & $\begin{array}{l}\text { Non- } \\
\text { binder }\end{array}$ & $\begin{array}{l}\text { Non- } \\
\text { binder }\end{array}$ & $\begin{array}{l}\text { Non- } \\
\text { binder }\end{array}$ & $\begin{array}{l}\text { Non- } \\
\text { binder }\end{array}$ & $\begin{array}{l}\text { Non- } \\
\text { binder }\end{array}$ & $\begin{array}{l}\text { Non- } \\
\text { binder }\end{array}$ & $\begin{array}{l}\text { Non- } \\
\text { binder }\end{array}$ & $\begin{array}{l}\text { Non- } \\
\text { binder }\end{array}$ & $\begin{array}{l}\text { Non- } \\
\text { binder }\end{array}$ & $\begin{array}{l}\text { Non- } \\
\text { binder }\end{array}$ & $\begin{array}{l}\text { Non- } \\
\text { binder }\end{array}$ & $\begin{array}{l}\text { Non- } \\
\text { binder }\end{array}$ \\
\hline 69 & $\begin{array}{l}\text { Non- } \\
\text { binder }\end{array}$ & $\begin{array}{l}\text { Non- } \\
\text { binder }\end{array}$ & $\begin{array}{l}\text { Non- } \\
\text { binder }\end{array}$ & $\begin{array}{l}\text { Non- } \\
\text { binder }\end{array}$ & $\begin{array}{l}\text { Non- } \\
\text { binder }\end{array}$ & $\begin{array}{l}\text { Non- } \\
\text { binder }\end{array}$ & $\begin{array}{l}\text { Non- } \\
\text { binder }\end{array}$ & $\begin{array}{l}\text { Non- } \\
\text { binder }\end{array}$ & $\begin{array}{l}\text { Non- } \\
\text { binder }\end{array}$ & $\begin{array}{l}\text { Non- } \\
\text { binder }\end{array}$ & $\begin{array}{l}\text { Non- } \\
\text { binder }\end{array}$ & $\begin{array}{l}\text { Non- } \\
\text { binder }\end{array}$ & $\begin{array}{l}\text { Non- } \\
\text { binder }\end{array}$ & $\begin{array}{l}\text { Non- } \\
\text { binder }\end{array}$ & $\begin{array}{l}\text { Non- } \\
\text { binder }\end{array}$ \\
\hline 70 & $\begin{array}{l}\text { Non- } \\
\text { binder }\end{array}$ & $\begin{array}{l}\text { Non- } \\
\text { binder }\end{array}$ & $\begin{array}{l}\text { Non- } \\
\text { binder }\end{array}$ & $\begin{array}{l}\text { Non- } \\
\text { binder }\end{array}$ & $\begin{array}{l}\text { Non- } \\
\text { binder }\end{array}$ & $\begin{array}{l}\text { Non- } \\
\text { binder }\end{array}$ & $\begin{array}{l}\text { Non- } \\
\text { binder }\end{array}$ & $\begin{array}{l}\text { Non- } \\
\text { binder }\end{array}$ & $\begin{array}{l}\text { Non- } \\
\text { binder }\end{array}$ & $\begin{array}{l}\text { Non- } \\
\text { binder }\end{array}$ & $\begin{array}{l}\text { Non- } \\
\text { binder }\end{array}$ & $\begin{array}{l}\text { Non- } \\
\text { binder }\end{array}$ & $\begin{array}{l}\text { Non- } \\
\text { binder }\end{array}$ & $\begin{array}{l}\text { Non- } \\
\text { binder }\end{array}$ & $\begin{array}{l}\text { Non- } \\
\text { binder }\end{array}$ \\
\hline 71 & $\begin{array}{l}\text { Non- } \\
\text { binder }\end{array}$ & $\begin{array}{l}\text { Non- } \\
\text { binder }\end{array}$ & $\begin{array}{l}\text { Non- } \\
\text { binder }\end{array}$ & $\begin{array}{l}\text { Non- } \\
\text { binder }\end{array}$ & $\begin{array}{l}\text { Non- } \\
\text { binder }\end{array}$ & $\begin{array}{l}\text { Non- } \\
\text { binder }\end{array}$ & $\begin{array}{l}\text { Non- } \\
\text { binder }\end{array}$ & $\begin{array}{l}\text { Non- } \\
\text { binder }\end{array}$ & $\begin{array}{l}\text { Non- } \\
\text { binder }\end{array}$ & $\begin{array}{l}\text { Non- } \\
\text { binder }\end{array}$ & $\begin{array}{l}\text { Non- } \\
\text { binder }\end{array}$ & $\begin{array}{l}\text { Non- } \\
\text { binder }\end{array}$ & $\begin{array}{l}\text { Non- } \\
\text { binder }\end{array}$ & $\begin{array}{l}\text { Non- } \\
\text { binder }\end{array}$ & $\begin{array}{l}\text { Non- } \\
\text { binder }\end{array}$ \\
\hline 72 & $\begin{array}{l}\text { Non- } \\
\text { binder }\end{array}$ & $\begin{array}{l}\text { Non- } \\
\text { binder }\end{array}$ & $\begin{array}{l}\text { Non- } \\
\text { binder }\end{array}$ & $\begin{array}{l}\text { Non- } \\
\text { binder }\end{array}$ & $\begin{array}{l}\text { Non- } \\
\text { binder }\end{array}$ & $\begin{array}{l}\text { Non- } \\
\text { binder }\end{array}$ & $\begin{array}{l}\text { Non- } \\
\text { binder }\end{array}$ & $\begin{array}{l}\text { Non- } \\
\text { binder }\end{array}$ & $\begin{array}{l}\text { Non- } \\
\text { binder }\end{array}$ & $\begin{array}{l}\text { Non- } \\
\text { binder }\end{array}$ & $\begin{array}{l}\text { Non- } \\
\text { binder }\end{array}$ & $\begin{array}{l}\text { Non- } \\
\text { binder }\end{array}$ & $\begin{array}{l}\text { Non- } \\
\text { binder }\end{array}$ & $\begin{array}{l}\text { Non- } \\
\text { binder }\end{array}$ & $\begin{array}{l}\text { Non- } \\
\text { binder }\end{array}$ \\
\hline 73 & $\begin{array}{l}\text { Non- } \\
\text { binder }\end{array}$ & $\begin{array}{l}\text { Non- } \\
\text { binder }\end{array}$ & $\begin{array}{l}\text { Non- } \\
\text { binder }\end{array}$ & $\begin{array}{l}\text { Non- } \\
\text { binder }\end{array}$ & $\begin{array}{l}\text { Non- } \\
\text { binder }\end{array}$ & $\begin{array}{l}\text { Non- } \\
\text { binder }\end{array}$ & $\begin{array}{l}\text { Non- } \\
\text { binder }\end{array}$ & $\begin{array}{l}\text { Non- } \\
\text { binder }\end{array}$ & $\begin{array}{l}\text { Non- } \\
\text { binder }\end{array}$ & $\begin{array}{l}\text { Non- } \\
\text { binder }\end{array}$ & $\begin{array}{l}\text { Non- } \\
\text { binder }\end{array}$ & $\begin{array}{l}\text { Non- } \\
\text { binder }\end{array}$ & $\begin{array}{l}\text { Non- } \\
\text { binder }\end{array}$ & $\begin{array}{l}\text { Non- } \\
\text { binder }\end{array}$ & $\begin{array}{l}\text { Non- } \\
\text { binder }\end{array}$ \\
\hline 74 & $\begin{array}{l}\text { Non- } \\
\text { binder }\end{array}$ & $\begin{array}{l}\text { Non- } \\
\text { binder }\end{array}$ & $\begin{array}{l}\text { Non- } \\
\text { binder }\end{array}$ & $\begin{array}{l}\text { Non- } \\
\text { binder }\end{array}$ & $\begin{array}{l}\text { Non- } \\
\text { binder }\end{array}$ & $\begin{array}{l}\text { Non- } \\
\text { binder }\end{array}$ & $\begin{array}{l}\text { Non- } \\
\text { binder }\end{array}$ & $\begin{array}{l}\text { Non- } \\
\text { binder }\end{array}$ & $\begin{array}{l}\text { Non- } \\
\text { binder }\end{array}$ & $\begin{array}{l}\text { Non- } \\
\text { binder }\end{array}$ & $\begin{array}{l}\text { Non- } \\
\text { binder }\end{array}$ & $\begin{array}{l}\text { Non- } \\
\text { binder }\end{array}$ & $\begin{array}{l}\text { Non- } \\
\text { binder }\end{array}$ & $\begin{array}{l}\text { Non- } \\
\text { binder }\end{array}$ & $\begin{array}{l}\text { Non- } \\
\text { binder }\end{array}$ \\
\hline 75 & $\begin{array}{l}\text { Non- } \\
\text { binder }\end{array}$ & $\begin{array}{l}\text { Non- } \\
\text { binder }\end{array}$ & $\begin{array}{l}\text { Non- } \\
\text { binder }\end{array}$ & $\begin{array}{l}\text { Non- } \\
\text { binder }\end{array}$ & $\begin{array}{l}\begin{array}{l}\text { Non- } \\
\text { binder }\end{array} \\
\end{array}$ & \begin{tabular}{|l|}
$\begin{array}{l}\text { Non- } \\
\text { binder }\end{array}$ \\
\end{tabular} & $\begin{array}{l}\text { Non- } \\
\text { binder }\end{array}$ & $\begin{array}{l}\text { Non- } \\
\text { binder }\end{array}$ & $\begin{array}{l}\text { Non- } \\
\text { binder }\end{array}$ & $\begin{array}{l}\text { Non- } \\
\text { binder }\end{array}$ & $\begin{array}{l}\text { Non- } \\
\text { binder }\end{array}$ & $\begin{array}{l}\text { Non- } \\
\text { binder }\end{array}$ & $\begin{array}{l}\text { Non- } \\
\text { binder }\end{array}$ & $\begin{array}{l}\text { Non- } \\
\text { binder }\end{array}$ & $\begin{array}{l}\text { Non- } \\
\text { binder }\end{array}$ \\
\hline
\end{tabular}

Table 27. Predicted activity of the top hit compounds towards the panel of protein toxicity targets.

MD simulation using NAMD software package version $2.10^{79}$. The protein was parameterized using AMBER ff14SB force field. The system was solvated with TIP3P water model in a box of $15 \AA$ on all sides. Counter ions were added to neutralize the system. The system was simulated in NVT with a temperature of $300 \mathrm{~K}$ and with an interval output every $2 \mathrm{fs}^{80}$. Long-range interactions were evaluated using particle mesh Ewald method ${ }^{81}$. Bond constraints were applied using SHAKE algorithm ${ }^{82}$.

Received: 19 July 2019; Accepted: 1 October 2019;

Published online: 19 November 2019

\section{References}

1. Zink, A., Grabner, W., Reischl, U., Wolf, H. \& Nerlich, A. Molecular study on human tuberculosis in three geographically distinct and time delineated populations from ancient egypt. Epidemiol. \& Infect. 130, 239-249 (2003).

2. Tuli, S. Tuberculosis of the spine: a historical review. Clin. Orthop. Relat. Res. (1976-2007) 460, 29-38 (2007)

3. Daniel, T. M. The impact of tuberculosis on civilization. Infect. disease clinics North Am. 18, 157-165 (2004).

4. Delogu, G., Sali, M. \& Fadda, G. The biology of mycobacterium tuberculosis infection. Mediterr. journal hematology infectious diseases 5 (2013).

5. Organization, W. H. et al. Global tuberculosis report 2016. 2016. View Article (2016). 
6. MacNeil, A., Glaziou, P., Sismanidis, C., Maloney, S. \& Floyd, K. Global epidemiology of tuberculosis and progress toward achieving global targets-2017. Morb. Mortal. Wkly. Rep. 68, 263 (2019).

7. Mohajan, $\mathrm{H}$. Tuberculosis is a fatal disease among some developing countries of the world. (2014).

8. Vianzon, R., Garfin, A. M. C., Lagos, A. \& Belen, R. The tuberculosis profile of the philippines, 2003-2011: advancing dots and beyond. West. Pac. Surveillance Response 4 (2013).

9. Organization, W. H. et al. The global mdr-tb \& xdr-tb response plan 2007-2008. Tech. Rep., Geneva: World Health Organization (2007).

10. Raviglione, M. C. \& Smith, I. M. Xdr tuberculosis-implications for global public health. New Engl. J. Medicine 356, 656-659 (2007).

11. Chatterjee, D. The mycobacterial cell wall: structure, biosynthesis and sites of drug action. Curr. opinion chemical biology 1, 579-588 (1997).

12. Brennan, P. \& Besra, G. Structure, Function and Biogenesis of the Mycobacterial Cell Wall. Biochemical Society transactions, 25(1), 188-194 (1997).

13. Wilkinson, B. L., Long, H., Sim, E. \& Fairbanks, A. J. Synthesis of arabino glycosyl triazoles as potential inhibitors of mycobacterial cell wall biosynthesis. Bioorganic \& medicinal chemistry letters 18, 6265-6267 (2008).

14. Velayati, A. A. et al. Differences in cell wall thickness between resistant and nonresistant strains of mycobacterium tuberculosis: using transmission electron microscopy. Chemotherapy 55, 303-307 (2009).

15. Raviglione, M. C. \& Uplekar, M. W. Who's new stop tb strategy. The Lancet 367, 952-955 (2006).

16. Peltier, P. et al. Synthetic udp-furanoses as potent inhibitors of mycobacterial galactan biogenesis. Chem. \& biology 17, 1356-1366 (2010).

17. Crick, D. C., Mahapatra, S. \& Brennan, P. J. Biosynthesis of the arabinogalactan-peptidoglycan complex of mycobacterium tuberculosis. Glycobiology 11, 107R-118R (2001).

18. McNeil, M. Arabinogalactan in mycobacteria: structure, biosynthesis, and genetics. Genet. bacterial polysaccharides. CRC Press. Boca Raton, FL 207-223 (1999).

19. Alderwick, L. J., Harrison, J., Lloyd, G. S. \& Birch, H. L. The mycobacterial cell wall-peptidoglycan and arabinogalactan. Cold Spring Harb. perspectives medicine 5, a021113 (2015).

20. Wheatley, R. W., Zheng, R. B., Richards, M. R., Lowary, T. L. \& Ng, K. K. Tetrameric structure of the glft2 galactofuranosyltransferase reveals a scaffold for the assembly of mycobacterial arabinogalactan. J. Biol. Chem. 287, 28132-28143 (2012).

21. Rose, N. L. et al. Expression, purification, and characterization of a galactofuranosyltransferase involved in mycobacterium $t$ uberculosis arabinogalactan biosynthesis. J. Am. Chem. Soc. 128, 6721-6729 (2006).

22. Completo, G. C. \& Lowary, T. L. Synthesis of galactofuranose-containing acceptor substrates for mycobacterial galactofuranosyltransferases. The J. organic chemistry 73, 4513-4525 (2008).

23. Vembaiyan, K., Pearcey, J. A., Bhasin, M., Lowary, T. L. \& Zou, W. Synthesis of sugar-amino acid-nucleosides as potential glycosyltransferase inhibitors. Bioorganic \& medicinal chemistry 19, 58-66 (2011).

24. Lee, R. E., Smith, M. D., Pickering, L. \& Fleet, G. W. An approach to combinatorial library generation of galactofuranose mimics as potential inhibitors of mycobacterial cell wall biosynthesis: Synthesis of a peptidomimetic of uridine 5-diphosphogalactofuranose (udp-galf). Tetrahedron letters 40, 8689-8692 (1999).

25. Liautard, V., Desvergnes, V. \& Martin, O. R. Stereoselective synthesis of a-c-substituted 1, 4-dideoxy-1, 4-imino-dgalactitols. toward original udp-gal $\mathrm{f}$ mimics via cross-metathesis. Org. letters 8, 1299-1302 (2006).

26. Liautard, V., Desvergnes, V., Itoh, K., Liu, H.-w \& Martin, O. R. Convergent and stereoselective synthesis of iminosugarcontaining gal $f$ and udp-gal $f$ mimicks: Evaluation as inhibitors of udp-gal mutase. The J. organic chemistry 73, 3103-3115 (2008).

27. Liautard, V., Christina, A. E., Desvergnes, V. \& Martin, O. R. Diastereoselective synthesis of novel iminosugar-containing udp-gal $\mathrm{f}$ mimics: Potential inhibitors of udp-gal mutase and udp-gal $\mathrm{f}$ transferases. The J. organic chemistry 71, 7337-7345 (2006).

28. Desvergnes, S. et al. Stereoselective synthesis of b-1-c-substituted 1, 4-dideoxy-1, 4-imino-d-galactitols and evaluation as udpgalactopyranose mutase inhibitors. Bioorganic \& medicinal chemistry 15, 6443-6449 (2007).

29. Li, J. \& Lowary, T. L. Sulfonium ions as inhibitors of the mycobacterial galactofuranosyltransferase glft2. MedChemComm 5 , $1130-1137$ (2014).

30. Yoshikawa, M. et al. Salacinol, potent antidiabetic principle with unique thiosugar sulfonium sulfate structure from the ayurvedic traditional medicine salacia reticulata in sri lanka and india. Tetrahedron Lett. 38, 8367-8370 (1997).

31. Veerapen, N., Yuan, Y., Sanders, D. A. \& Pinto, B. M. Synthesis of novel ammonium and selenonium ions and their evaluation as inhibitors of udp-galactopyranose mutase. Carbohydr. research 339, 2205-2217 (2004).

32. Ghavami, A., Chen, J. J.-w \& Pinto, B. M. Synthesis of a novel class of sulfonium ions as potential inhibitors of udp-galactopyranose mutase. Carbohydr. research 339, 401-407 (2004).

33. Tefsen, B., Ram, A. F., van Die, I. \& Routier, F. H. Galactofuranose in eukaryotes: aspects of biosynthesis and functional impact. Glycobiology 22, 456-469 (2011).

34. Owen, D. J. et al. Synthesis and evaluation of galactofuranosyl n, n-dialkyl sulfenamides and sulfonamides as antimycobacterial agents. Bioorganic \& medicinal chemistry letters 17, 2274-2277 (2007).

35. Roe, D. R. \& Cheatham, T. E. III Ptraj and cpptraj: software for processing and analysis of molecular dynamics trajectory data. J. chemical theory computation $\mathbf{9}, 3084-3095$ (2013).

36. Case, D. A. et al. AMBER 2017, University of California, San Francisco (2017).

37. Marvin 19.15.0, 2018, ChemAxon (http://www.chemaxon.com).

38. Dacanay, F., Ladra, M., Junio, H. \& Nellas, R. Molecular affinity of mabolo extracts to an octopamine receptor of a fruit fly. Molecules 22, 1677 (2017).

39. Ortiz, C. L. D., Matel, H. D. \& Nellas, R. B. In silico insights on enhancing thermostability and activity of a plant fructosyltransferase from pachysandra terminalis via introduction of disulfide bridges. J. Mol. Graph. Model. 89, 250-260 (2019).

40. Trott, O. \& Olson, A. J. AutoDock Vina: improving the speed and accuracy of docking with a new scoring function, efficient optimization and multithreading. Journal of Computational Chemistry 31 455-461 (2010).

41. Silhavy, T. J., Kahne, D. \& Walker, S. The bacterial cell envelope. Cold Spring Harb. perspectives biology 2, a000414 (2010).

42. Favrot, L. \& Ronning, D. R. Targeting the mycobacterial envelope for tuberculosis drug development. Expert. review anti-infective therapy 10, 1023-1036 (2012).

43. Mikušová, K. et al. Identification of a novel galactosyl transferase involved in biosynthesis of the mycobacterial cell wall. J. bacteriology 188, 6592-6598 (2006).

44. Beláňová, M. et al. Galactosyl transferases in mycobacterial cell wall synthesis. J. bacteriology 190, 1141-1145 (2008).

45. Kremer, L. et al. Galactan biosynthesis in mycobacterium tuberculosis identification of a bifunctional udpgalactofuranosyltransferase. J. Biol. Chem. 276, 26430-26440 (2001).

46. Davis, C. B. et al. Synthesis and biological evaluation of galactofuranosyl alkyl thioglycosides as inhibitors of mycobacteria. Carbohydr. research 342, 1773-1780 (2007).

47. Lee, R. E. et al. Inhibition of udp-gal mutase and mycobacterial galactan biosynthesis by pyrrolidine analogues of galactofuranose. Tetrahedron letters 38, 6733-6736 (1997).

48. Scherman, M. S. et al. Drug targeting mycobacterium tuberculosis cell wall synthesis: development of a microtiter platebased screen for udp-galactopyranose mutase and identification of an inhibitor from a uridine-based library. Antimicrob. agents chemotherapy 47, 378-382 (2003). 
49. Tangallapally, R. P. et al. Synthesis and evaluation of nitrofuranylamides as novel antituberculosis agents. J. medicinal chemistry 47, 5276-5283 (2004).

50. Carlson, E. E., May, J. F. \& Kiessling, L. L. Chemical probes of udp-galactopyranose mutase. Chem. \& biology 13, 825-837 (2006).

51. Pan, W., Ansiaux, C. \& Vincent, S. P. Synthesis of acyclic galactitol-and lyxitol-aminophosphonates as inhibitors of udpgalactopyranose mutase. Tetrahedron letters 48, 4353-4356 (2007).

52. Yu, W. \& MacKerell, A. D. Computer-aided drug design methods. In Antibiotics, 85-106 (Springer, 2017).

53. Weaver, D. F. Principles and practice of computer-aided drug design as applied to the discovery of antiepileptic agents. In Computational Neuroscience in Epilepsy, 515-XIX (Elsevier, 2008).

54. Scriven, E. V. Turnbull k. Chem. Rev 88, 297 (1988).

55. Smith, P. A. Aryl and heteroaryl azides and nitrenes. Azides nitrenes, reactivity utility 95-204 (1984).

56. Takayama, Y., Kusamori, K. \& Nishikawa, M. Click chemistry as a tool for cell engineering and drug delivery. Molecules 24, 172 (2019).

57. Griffin, R. J. 3 the medicinal chemistry of the azido group. In Progress in medicinal chemistry, vol. 31, 121-232 (Elsevier, 1994).

58. de Souza, M. V. N., Bispo, M. d. L. F., Gonçalves, R. S. B. \& Kaiser, C. R. Thiourea derivatives: A promising class against hiv/tb coinfection. In Global View of HIV Infection (IntechOpen, 2011).

59. Shakeel, A., Altaf, A. A., Qureshi, A. M. \& Badshah, A. Thiourea derivatives in drug design and medicinal chemistry: A short review. J. Drug Des. Med. Chem 2, 10-20 (2016).

60. Ohara, K. et al. Amine- guanidine switch: A promising approach to improve dna binding and antiproliferative activities. J. medicinal chemistry 50, 6465-6475 (2007).

61. Brown, J. R., Nishimura, Y. \& Esko, J. D. Synthesis and biological evaluation of gem-diamine 1-n-iminosugars related to l-iduronic acid as inhibitors of heparan sulfate 2-o-sulfotransferase. Bioorganic \& medicinal chemistry letters 16, 532-536 (2006).

62. Saczewski, F. \& Balewski, Ł. Biological activities of guanidine compounds. Expert. opinion on therapeutic patents 19, 1417-1448 (2009).

63. Mossa, J. S., Taragan, A. H. U. K. \& Hassan, M. M. Streptomycin. In Analytical Profiles of Drug Substances, vol. 16, 507-609 (Elsevier, 1987).

64. Lee, R. E., Brennan, P. J. \& Besra, G. S. Mycobacterial arabinan biosynthesis: the use of synthetic arabinoside acceptors in the development of an arabinosyl transfer assay. Glycobiology 7, 1121-1128 (1997).

65. Alam, S. \& Khan, F. 3d-qsar, docking, adme/tox studies on flavone analogs reveal anticancer activity through tankyrase inhibition. Sci. reports 9,5414 (2019).

66. Verma, J., Khedkar, V. M. \& Coutinho, E. C. 3d-qsar in drug design-a review. Curr. topics medicinal chemistry 10, 95-115 (2010).

67. Daina, A., Michielin, O. \& Zoete, V. Swissadme: a free web tool to evaluate pharmacokinetics, drug-likeness and medicinal chemistry friendliness of small molecules. Sci. reports 7, 42717 (2017).

68. Banerjee, P., Eckert, A. O., Schrey, A. K. \& Preissner, R. Protox-ii: a webserver for the prediction of toxicity of chemicals. Nucleic acids research 46, W257-W263 (2018).

69. van Breemen, R. B. \& Li, Y. Caco-2 cell permeability assays to measure drug absorption. Expert. opinion on drug metabolism \& toxicology 1, 175-185 (2005).

70. Alam, S. \& Khan, F. Virtual screening, docking, admet and system pharmacology studies on garcinia caged xanthone derivatives for anticancer activity. Sci. reports 8, 5524 (2018).

71. Brenk, R. et al. Lessons learnt from assembling screening libraries for drug discovery for neglected diseases. ChemMed-Chem: Chem. Enabling Drug Discov. 3, 435-444 (2008).

72. Potts, R. O. \& Guy, R. H. Predicting skin permeability. Pharm. research 9, 663-669 (1992).

73. Testa, B. \& Kraemer, S. D. The biochemistry of drug metabolism-an introduction: part 3. reactions of hydrolysis and their enzymes. Chem. \& biodiversity 4, 2031-2122 (2007).

74. van Waterschoot, R. A. \& Schinkel, A. H. A critical analysis of the interplay between cytochrome p450 3a and pglycoprotein: recent insights from knockout and transgenic mice. Pharmacol. reviews 63, 390-410 (2011).

75. Saeidnia, S., Manayi, A. \& Abdollahi, M. The pros and cons of the in-silico pharmaco-toxicology in drug discovery and development. Int J Pharm 9, 176-181 (2013).

76. Raies, A. B. \& Bajic, V. B. In silico toxicology: computational methods for the prediction of chemical toxicity. Wiley Interdiscip. Rev. Comput. Mol. Sci. 6, 147-172 (2016).

77. Drwal, M. N., Banerjee, P., Dunkel, M., Wettig, M. R. \& Preissner, R. Protox: a web server for the in silico prediction of rodent oral toxicity. Nucleic acids research 42, W53-W58 (2014).

78. Lounkine, E. et al. Large-scale prediction and testing of drug activity on side-effect targets. Nature 486, 361 (2012).

79. Phillips, J. C. et al. Scalable molecular dynamics with namd. J. computational chemistry 26, 1781-1802 (2005).

80. Adelman, S. \& Doll, J. Generalized langevin equation approach for atom/solid-surface scattering: General formulation for classical scattering off harmonic solids. The J. chemical physics 64, 2375-2388 (1976).

81. Darden, T., York, D. \& Pedersen, L. Particle mesh ewald: An $\mathrm{n} \log (\mathrm{n})$ method for ewald sums in large systems. The J. chemical physics 98, 10089-10092 (1993)

82. Ryckaert, J.-P., Ciccotti, G. \& Berendsen, H. J. Numerical integration of the cartesian equations of motion of a system with constraints: molecular dynamics of n-alkanes. J. computational physics 23, 327-341 (1977).

\section{Acknowledgements}

We would like to acknowledge the Advanced Science and Technology Institute (ASTI) and the Computing and Archiving Research Environment (CoARE) of the Department of Science and Technology, Philippines for the allocation of computing resources. This work is partly supported by the Office of the Vice President for Academic Affairs, University of the Philippines - Balik PhD Program, Office of the Vice Chancellor for Research and Development - University of the Philippines Diliman, and DOST-NEWTON Fund.

\section{Author contributions}

C.L.D.O conducted analyses and manuscript writing. G.C.C., R.C.N., and R.B.N. suggested the design of the compounds. All authors reviewed the manuscript.

\section{Competing interests}

The authors declare no competing interests.

\section{Additional information}

Correspondence and requests for materials should be addressed to R.B.N.

Reprints and permissions information is available at www.nature.com/reprints. 
Publisher's note Springer Nature remains neutral with regard to jurisdictional claims in published maps and institutional affiliations.

(c) (i) Open Access This article is licensed under a Creative Commons Attribution 4.0 International License, which permits use, sharing, adaptation, distribution and reproduction in any medium or format, as long as you give appropriate credit to the original author(s) and the source, provide a link to the Creative Commons license, and indicate if changes were made. The images or other third party material in this article are included in the article's Creative Commons license, unless indicated otherwise in a credit line to the material. If material is not included in the article's Creative Commons license and your intended use is not permitted by statutory regulation or exceeds the permitted use, you will need to obtain permission directly from the copyright holder. To view a copy of this license, visit http://creativecommons.org/licenses/by/4.0/.

(c) The Author(s) 2019 